Supplement of Atmos. Chem. Phys., 21, 10799-10824, 2021

https://doi.org/10.5194/acp-21-10799-2021-supplement

(C) Author(s) 2021. CC BY 4.0 License.

(c) (i)

Supplement of

\title{
Molecular composition and volatility of multi-generation products formed from isoprene oxidation by nitrate radical
}

Rongrong Wu et al.

Correspondence to: Thomas F. Mentel (t.mentel@fz-juelich.de)

The copyright of individual parts of the supplement might differ from the article licence. 
Table S1: Possible permutation scheme for dimers formed through $\mathrm{RO}_{2}+\mathrm{R}^{\prime} \mathrm{O}_{2}$ reactions. Molecular formulas presented in dark colors (colored by isomers) are compounds detected by CIMS in this study, while those in light grey were not.

\begin{tabular}{|c|c|c|c|c|c|}
\hline $\mathrm{C}_{\mathrm{C}_{5} \mathrm{H}_{8} \mathrm{NO}_{\mathrm{x}}}^{\mathrm{C}_{5} \mathrm{H}_{8} \mathrm{NO}_{\mathrm{x}}}$ & $\mathrm{O}_{5}$ & $\mathbf{O}_{6}$ & $\mathbf{O}_{7}$ & $\mathbf{O}_{8}$ & $\mathbf{O}_{9}$ \\
\hline $\mathrm{O}_{5}$ & $\mathrm{C}_{10} \mathrm{H}_{16} \mathrm{~N}_{2} \mathrm{O}_{8}$ & & & & \\
\hline $\mathbf{O}_{6}$ & $\mathrm{C}_{10} \mathrm{H}_{16} \mathrm{~N}_{2} \mathrm{O}_{9}$ & $\mathrm{C}_{10} \mathrm{H}_{16} \mathrm{~N}_{2} \mathrm{O}_{10}$ & & & \\
\hline $\mathbf{O}_{7}$ & $\mathrm{C}_{10} \mathrm{H}_{16} \mathrm{~N}_{2} \mathrm{O}_{10}$ & $\mathrm{C}_{10} \mathrm{H}_{16} \mathrm{~N}_{2} \mathrm{O}_{11}$ & $\mathrm{C}_{10} \mathrm{H}_{16} \mathrm{~N}_{2} \mathrm{O}_{12}$ & & \\
\hline Os & $\mathrm{C}_{10} \mathrm{H}_{16} \mathrm{~N}_{2} \mathrm{O}_{11}$ & $\mathrm{C}_{10} \mathrm{H}_{16} \mathrm{~N}_{2} \mathrm{O}_{12}$ & $\mathrm{C}_{10} \mathrm{H}_{16} \mathrm{~N}_{2} \mathrm{O}_{13}$ & & \\
\hline O9 & $\mathrm{C}_{10} \mathrm{H}_{16} \mathrm{~N}_{2} \mathrm{O}_{12}$ & $\mathrm{C}_{10} \mathrm{H}_{16} \mathrm{~N}_{2} \mathrm{O}_{13}$ & $\mathrm{C}_{10} \mathrm{H}_{16} \mathrm{~N}_{2} \mathrm{O}_{14}$ & & \\
\hline $\mathbf{O}_{10}$ & $\mathrm{C}_{10} \mathrm{H}_{16} \mathrm{~N}_{2} \mathrm{O}_{13}$ & $\mathrm{C}_{10} \mathrm{H}_{16} \mathrm{~N}_{2} \mathrm{O}_{14}$ & $\mathrm{C}_{10} \mathrm{H}_{16} \mathrm{~N}_{2} \mathrm{O}_{15}$ & & \\
\hline $\mathbf{O}_{11}$ & $\mathrm{C}_{10} \mathrm{H}_{16} \mathrm{~N}_{2} \mathrm{O}_{14}$ & $\mathrm{C}_{10} \mathrm{H}_{16} \mathrm{~N}_{2} \mathrm{O}_{15}$ & $\mathrm{C}_{10} \mathrm{H}_{16} \mathrm{~N}_{2} \mathrm{O}_{16}$ & & \\
\hline $\mathbf{O}_{12}$ & $\mathrm{C}_{10} \mathrm{H}_{16} \mathrm{~N}_{2} \mathrm{O}_{15}$ & $\mathrm{C}_{10} \mathrm{H}_{16} \mathrm{~N}_{2} \mathrm{O}_{16}$ & $\mathrm{C}_{10} \mathrm{H}_{16} \mathrm{~N}_{2} \mathrm{O}_{17}$ & & \\
\hline $\mathrm{C}_{\mathrm{C}_{5} \mathrm{H}_{9} \mathrm{~N}_{2} \mathrm{O}_{\mathrm{y}}}^{\mathrm{C}_{5} \mathrm{H}_{8} \mathrm{NO}_{\mathrm{x}}}$ & $\mathrm{O}_{5}$ & $\mathbf{O}_{6}$ & $\mathbf{O}_{7}$ & $\mathbf{O}_{8}$ & O9 \\
\hline $\mathrm{O}_{9}$ & $\mathrm{C}_{10} \mathrm{H}_{17} \mathrm{~N}_{3} \mathrm{O}_{12}$ & $\mathrm{C}_{10} \mathrm{H}_{17} \mathrm{~N}_{3} \mathrm{O}_{13}$ & $\mathrm{C}_{10} \mathrm{H}_{17} \mathrm{~N}_{3} \mathrm{O}_{14}$ & $\mathrm{C}_{10} \mathrm{H}_{17} \mathrm{~N}_{3} \mathrm{O}_{15}$ & $\mathrm{C}_{10} \mathrm{H}_{17} \mathrm{~N}_{3} \mathrm{O}_{16}$ \\
\hline $\mathbf{O}_{10}$ & $\mathrm{C}_{10} \mathrm{H}_{17} \mathrm{~N}_{3} \mathrm{O}_{13}$ & $\mathrm{C}_{10} \mathrm{H}_{17} \mathrm{~N}_{3} \mathrm{O}_{14}$ & $\mathrm{C}_{10} \mathrm{H}_{17} \mathrm{~N}_{3} \mathrm{O}_{15}$ & $\mathrm{C}_{10} \mathrm{H}_{17} \mathrm{~N}_{3} \mathrm{O}_{16}$ & $\mathrm{C}_{10} \mathrm{H}_{17} \mathrm{~N}_{3} \mathrm{O}_{17}$ \\
\hline $\mathbf{O}_{11}$ & $\mathrm{C}_{10} \mathrm{H}_{17} \mathrm{~N}_{3} \mathrm{O}_{14}$ & $\mathrm{C}_{10} \mathrm{H}_{17} \mathrm{~N}_{3} \mathrm{O}_{15}$ & $\mathrm{C}_{10} \mathrm{H}_{17} \mathrm{~N}_{3} \mathrm{O}_{16}$ & $\mathrm{C}_{10} \mathrm{H}_{17} \mathrm{~N}_{3} \mathrm{O}_{17}$ & $\mathrm{C}_{10} \mathrm{H}_{17} \mathrm{~N}_{3} \mathrm{O}_{18}$ \\
\hline $\mathbf{O}_{12}$ & $\mathrm{C}_{10} \mathrm{H}_{17} \mathrm{~N}_{3} \mathrm{O}_{15}$ & $\mathrm{C}_{10} \mathrm{H}_{17} \mathrm{~N}_{3} \mathrm{O}_{16}$ & $\mathrm{C}_{10} \mathrm{H}_{17} \mathrm{~N}_{3} \mathrm{O}_{17}$ & $\mathrm{C}_{10} \mathrm{H}_{17} \mathrm{~N}_{3} \mathrm{O}_{18}$ & $\mathrm{C}_{10} \mathrm{H}_{17} \mathrm{~N}_{3} \mathrm{O}_{19}$ \\
\hline $\mathbf{O}_{13}$ & $\mathrm{C}_{10} \mathrm{H}_{17} \mathrm{~N}_{3} \mathrm{O}_{16}$ & $\mathrm{C}_{10} \mathrm{H}_{17} \mathrm{~N}_{3} \mathrm{O}_{17}$ & $\mathrm{C}_{10} \mathrm{H}_{17} \mathrm{~N}_{3} \mathrm{O}_{18}$ & $\mathrm{C}_{10} \mathrm{H}_{17} \mathrm{~N}_{3} \mathrm{O}_{19}$ & $\mathrm{C}_{10} \mathrm{H}_{17} \mathrm{~N}_{3} \mathrm{O}_{20}$ \\
\hline $\mathbf{O}_{14}$ & $\mathrm{C}_{10} \mathrm{H}_{17} \mathrm{~N}_{3} \mathrm{O}_{17}$ & $\mathrm{C}_{10} \mathrm{H}_{17} \mathrm{~N}_{3} \mathrm{O}_{18}$ & $\mathrm{C}_{10} \mathrm{H}_{17} \mathrm{~N}_{3} \mathrm{O}_{19}$ & $\mathrm{C}_{10} \mathrm{H}_{17} \mathrm{~N}_{3} \mathrm{O}_{20}$ & $\mathrm{C}_{10} \mathrm{H}_{17} \mathrm{~N}_{3} \mathrm{O}_{21}$ \\
\hline $\mathbf{O}_{15}$ & $\mathrm{C}_{10} \mathrm{H}_{17} \mathrm{~N}_{3} \mathrm{O}_{18}$ & $\mathrm{C}_{10} \mathrm{H}_{17} \mathrm{~N}_{3} \mathrm{O}_{19}$ & $\mathrm{C}_{10} \mathrm{H}_{17} \mathrm{~N}_{3} \mathrm{O}_{20}$ & $\mathrm{C}_{10} \mathrm{H}_{17} \mathrm{~N}_{3} \mathrm{O}_{21}$ & $\mathrm{C}_{10} \mathrm{H}_{17} \mathrm{~N}_{3} \mathrm{O}_{22}$ \\
\hline $\mathbf{O}_{16}$ & $\mathrm{C}_{10} \mathrm{H}_{17} \mathrm{~N}_{3} \mathrm{O}_{19}$ & $\mathrm{C}_{10} \mathrm{H}_{17} \mathrm{~N}_{3} \mathrm{O}_{20}$ & $\mathrm{C}_{10} \mathrm{H}_{17} \mathrm{~N}_{3} \mathrm{O}_{21}$ & $\mathrm{C}_{10} \mathrm{H}_{17} \mathrm{~N}_{3} \mathrm{O}_{22}$ & $\mathrm{C}_{10} \mathrm{H}_{17} \mathrm{~N}_{3} \mathrm{O}_{23}$ \\
\hline${ }_{\mathrm{C}_{5} \mathrm{H}_{9} \mathrm{~N}_{2} \mathrm{O}_{\mathrm{y}}}^{\mathrm{C}_{5} \mathrm{H}_{9} \mathrm{~N}_{2} \mathrm{O}_{\mathrm{y}}}$ & O9 & $\mathbf{O}_{10}$ & $\mathbf{O}_{11}$ & $\mathbf{O}_{12}$ & $\mathbf{O}_{13}$ \\
\hline $\mathrm{O}_{9}$ & $\mathrm{C}_{10} \mathrm{H}_{18} \mathrm{~N}_{4} \mathrm{O}_{16}$ & & & & \\
\hline $\mathbf{O}_{10}$ & $\mathrm{C}_{10} \mathrm{H}_{18} \mathrm{~N}_{4} \mathrm{O}_{17}$ & & & & \\
\hline $\mathbf{O}_{11}$ & $\mathrm{C}_{10} \mathrm{H}_{18} \mathrm{~N}_{4} \mathrm{O}_{18}$ & & & & \\
\hline $\mathrm{O}_{12}$ & $\mathrm{C}_{10} \mathrm{H}_{18} \mathrm{~N}_{4} \mathrm{O}_{19}$ & & & & \\
\hline $\mathbf{O}_{13}$ & $\mathrm{C}_{10} \mathrm{H}_{18} \mathrm{~N}_{4} \mathrm{O}_{20}$ & & & & \\
\hline $\mathbf{O}_{14}$ & $\mathrm{C}_{10} \mathrm{H}_{18} \mathrm{~N}_{4} \mathrm{O}_{21}$ & & & & \\
\hline $\mathbf{O}_{15}$ & $\mathrm{C}_{10} \mathrm{H}_{18} \mathrm{~N}_{4} \mathrm{O}_{22}$ & & & & \\
\hline $\mathbf{O}_{16}$ & $\mathrm{C}_{10} \mathrm{H}_{18} \mathrm{~N}_{4} \mathrm{O}_{23}$ & & & & \\
\hline
\end{tabular}


Table S2: Ions observed in the gas phase by CIMS and proposed possible products from isoprene oxidation by $\mathrm{NO}_{3}$

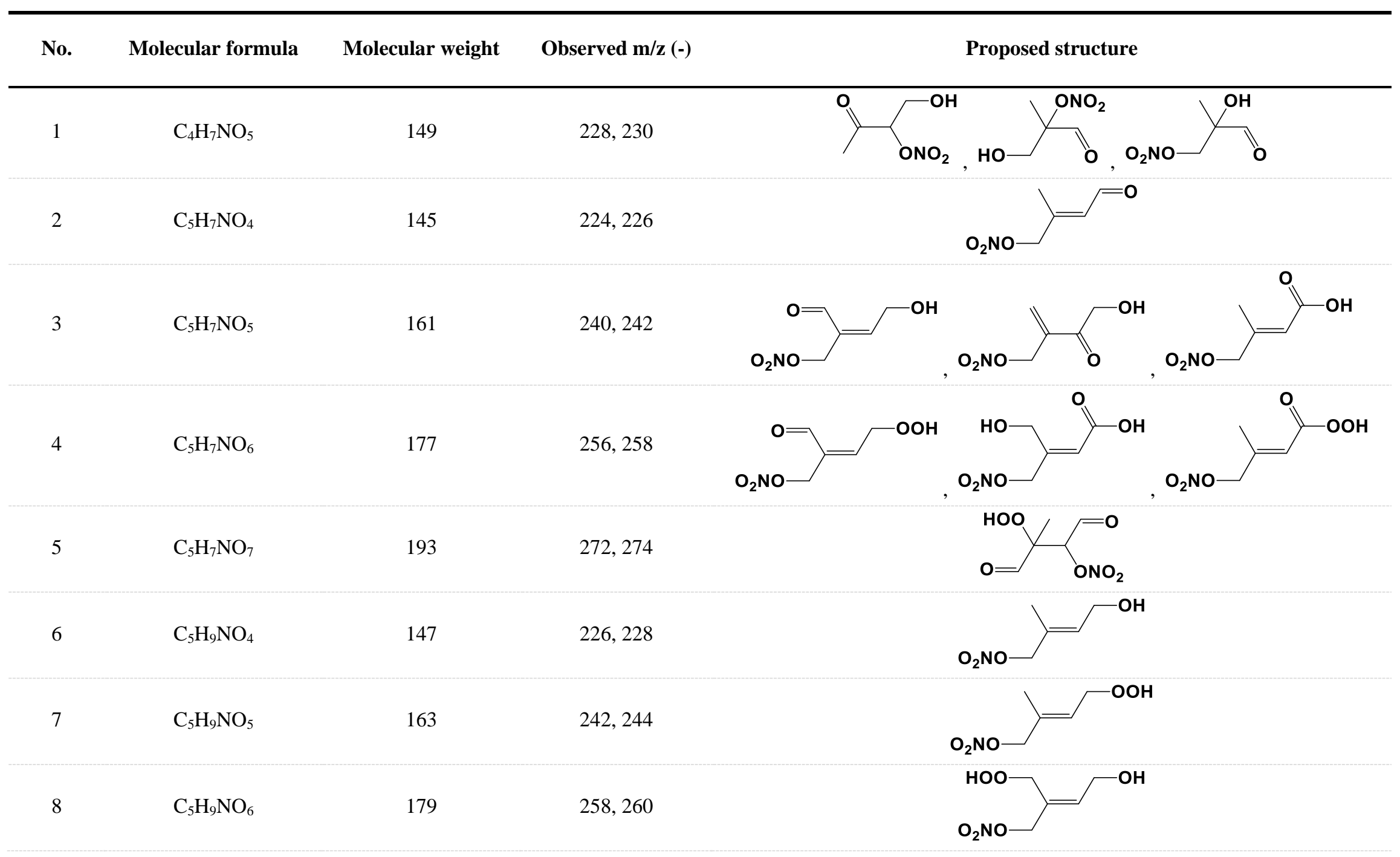




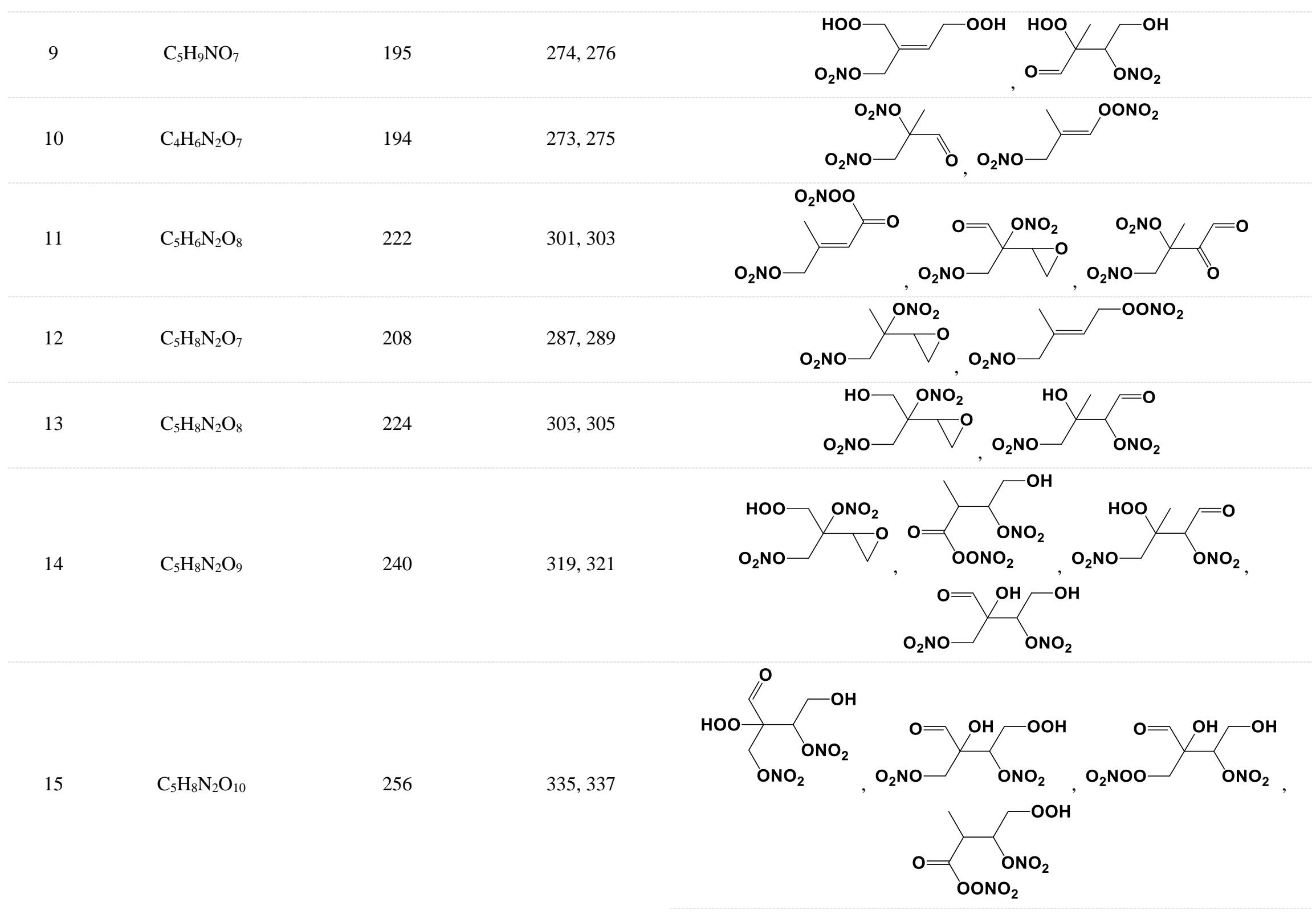




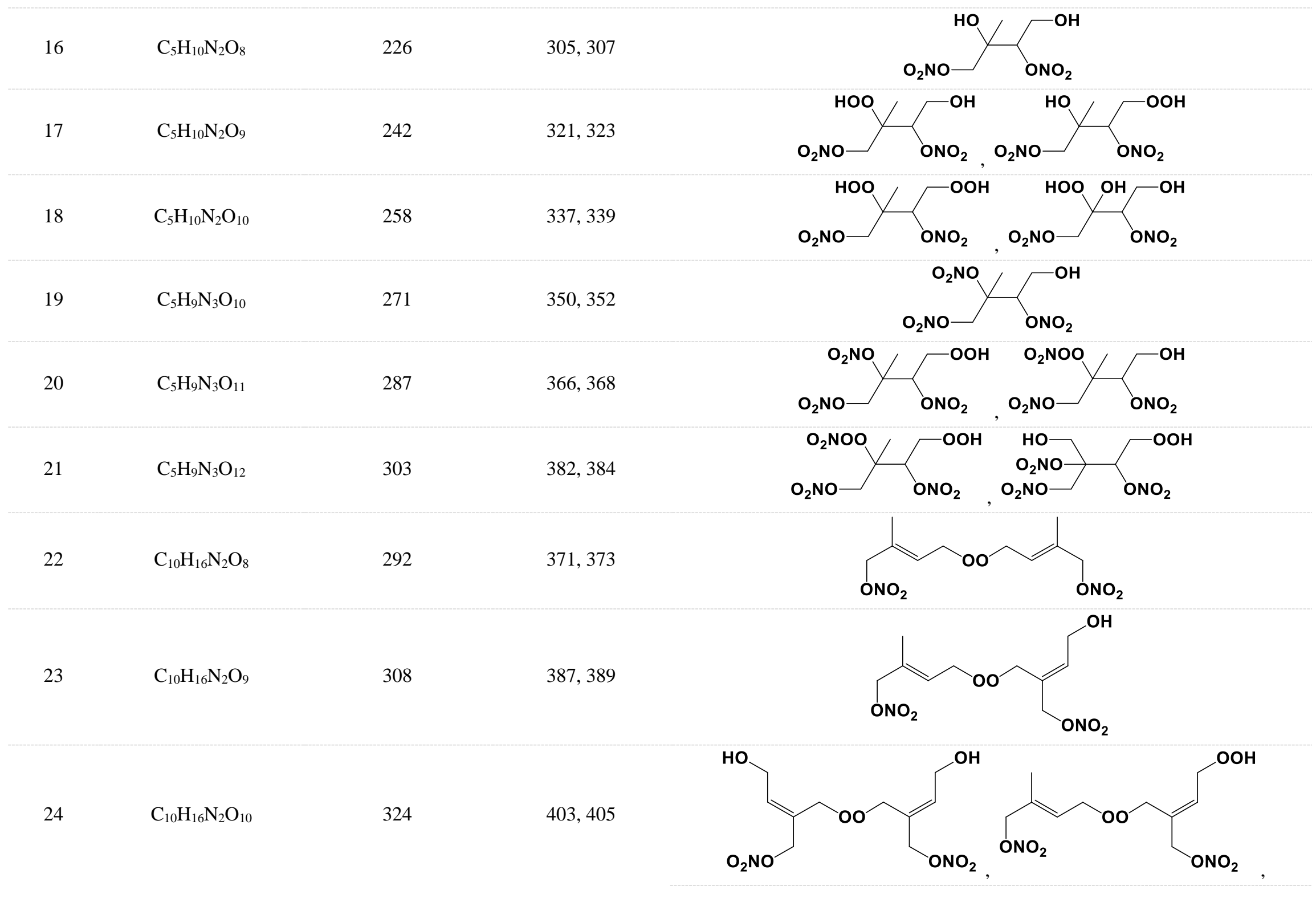




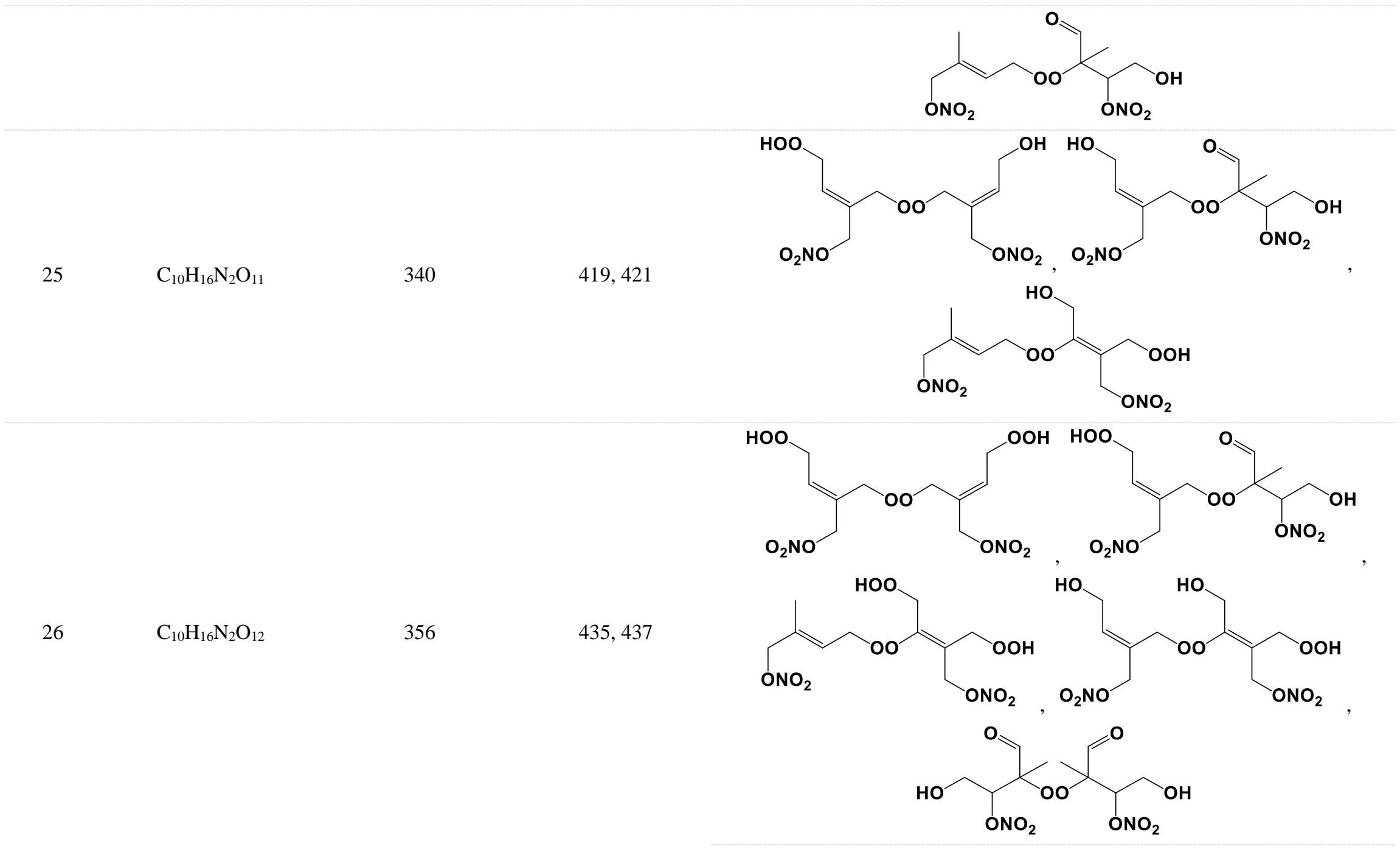



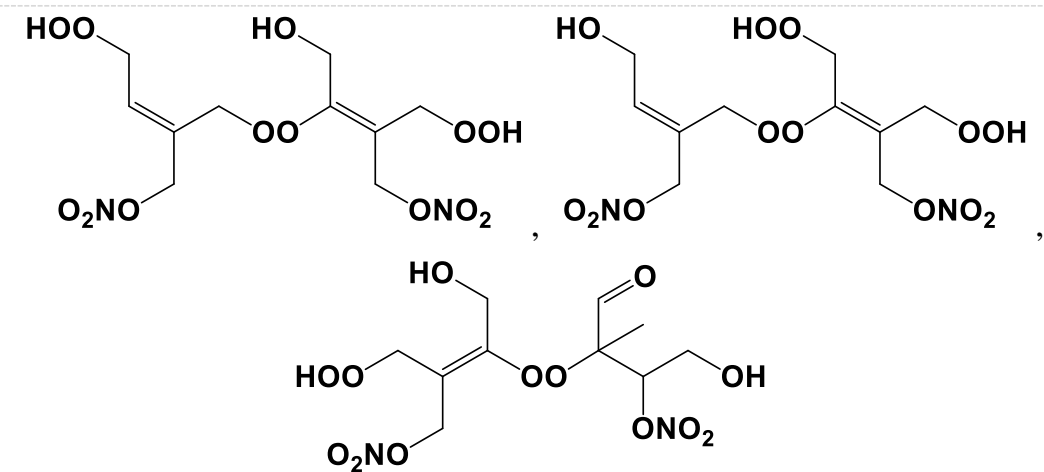

466, 468
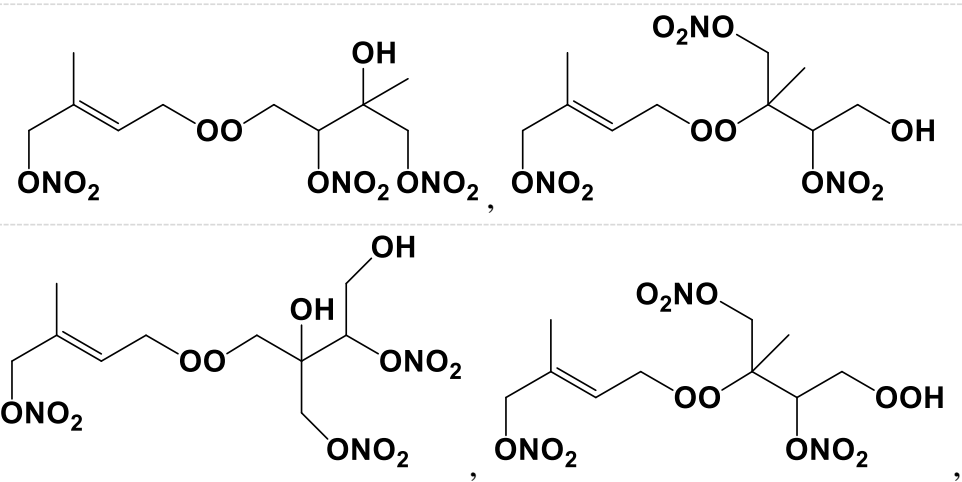<smiles>C/C(=C\CO[Na])CO[C@H](CO[N+](=O)[O-])[C@](C)(O)CO[Na]</smiles>

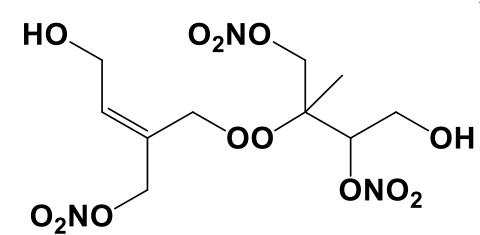

$\mathrm{ONO}_{2}$ $\mathrm{ONO}_{2} \mathrm{ONO}_{2}, \quad \mathrm{O}_{2} \mathrm{NO}^{-}$
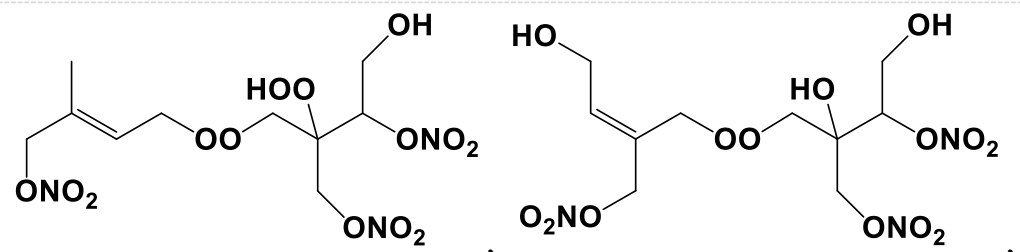


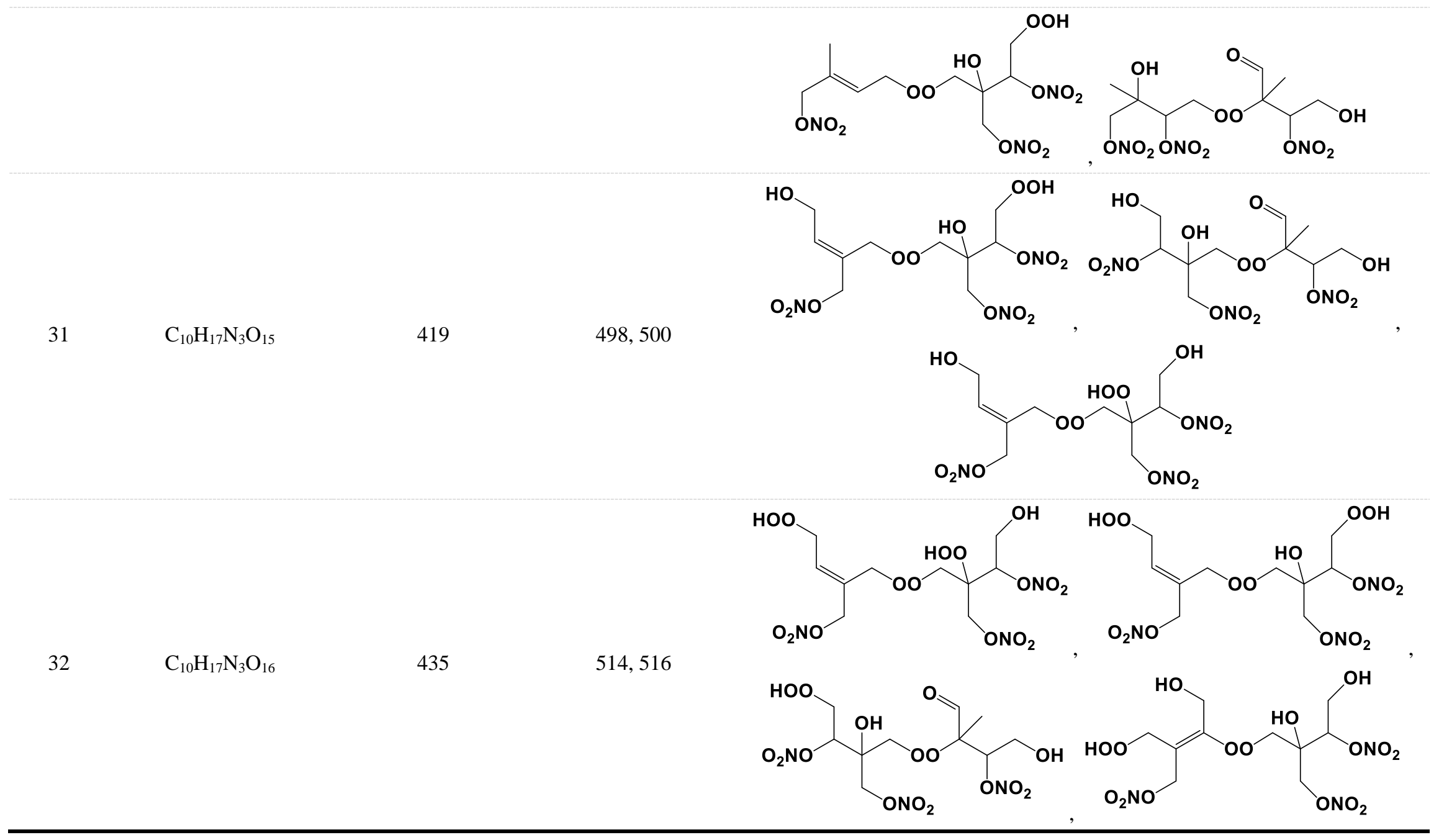


Table S3 lists the wall loss rates of dimers that used for wall-loss correction. Assuming that the dimers undergo irreversible gas-wall partitioning, then the overall wall loss rate of an organic species $i\left(k_{w, i}\right)$ can be written as Eq. (S1) (Zhang et al., 2015).

$k_{w, i}=\left(\frac{A}{V}\right)\left(\frac{\alpha_{w, i} \bar{v}_{i} / 4}{\pi \alpha_{w, i} \bar{v}_{i} / 8\left(D_{i} K_{e}\right)^{1 / 2}+1}\right)$

where $\mathrm{A} / \mathrm{V}$ is the surface to volume ratio of the SAPHIR chamber, $\alpha_{w, i}$ is the mass accommodation coefficient of species $i$ onto the chamber wall, $\bar{v}_{i}$ is the mean thermal speed of species $i, D_{i}$ is the molecular diffusivity, and $K_{e}$ is the coefficient of eddy diffusion. $D_{i}$ varies with molecular weight (MW) and is equal to $D_{\mathrm{CO}_{2}} \times\left(\mathrm{MW}_{\mathrm{CO}_{2}} / \mathrm{MW}_{i}\right)$ with $D_{\mathrm{CO}_{2}}=1.38 \times 10-5 \mathrm{~m}^{2} \mathrm{~s}^{-1}$ (Zhang et al., 2014). The mean speed of a gas molecule is defined as:

$\bar{v}_{i}=\left(\frac{8 N_{A} \kappa T}{\pi M W_{i}}\right)^{\frac{1}{2}}$

where $N_{A}$ is the Avagadro's number, $\kappa$ is the Boltzmann constant and $T$ is the temperature.

The value of $K_{e}$ for the SAPHIR chamber is estimated based on Eq. (S3) (Krechmer et al., 2016):

$K_{e}=0.004+\left(5.6 \times 10^{-3}\right)(V)^{0.74}$

In the irreversible partitioning case, the wall loss behavior is governed by the wall accommodation coefficient. $\alpha_{w, i}$ Zhang et al. (2015) observed a strong negative correlation between $\alpha_{w, i}$ and the saturation concentration $C_{i}^{*}$, and they formulated an empirical expression for $\alpha_{w, i}$ as a function of $C_{i}^{*}$ based on the measurements:

$\log _{10}\left(\alpha_{w, i}\right)=-0.1919 \times \log _{10}\left(C_{i}^{*}\right)-6.32$ 
Table S3: Estimated wall loss rates of different dimers

\begin{tabular}{cccccc}
\hline Formula & Volatility range $^{\mathbf{a}}$ & $\begin{array}{c}\text { Used for yield } \\
\text { calculation? }\end{array}$ & $\mathbf{k}_{\mathbf{w}}\left(\mathbf{s}^{\mathbf{1}}\right)$ & $\boldsymbol{\tau}_{\mathbf{w}}(\mathbf{s})$ & $\boldsymbol{\tau}_{\text {dil }}(\mathbf{s})$ \\
\hline $\mathrm{C}_{10} \mathrm{H}_{16} \mathrm{~N}_{2} \mathrm{O}_{8}$ & SVOC & No & $1.59 \mathrm{E}-05$ & $8.67 \mathrm{E}+04$ & $7.2 \mathrm{E}+04$ \\
$\mathrm{C}_{10} \mathrm{H}_{16} \mathrm{~N}_{2} \mathrm{O}_{9}$ & SVOC & No & $2.99 \mathrm{E}-05$ & $4.62 \mathrm{E}+04$ & $7.2 \mathrm{E}+04$ \\
$\mathrm{C}_{10} \mathrm{H}_{16} \mathrm{~N}_{2} \mathrm{O}_{10}$ & LVOC & Yes & $4.57 \mathrm{E}-05$ & $2.82 \mathrm{E}+04$ & $7.2 \mathrm{E}+04$ \\
$\mathrm{C}_{10} \mathrm{H}_{16} \mathrm{~N}_{2} \mathrm{O}_{11}$ & LVOC & Yes & $7.76 \mathrm{E}-05$ & $1.31 \mathrm{E}+04$ & $7.2 \mathrm{E}+04$ \\
$\mathrm{C}_{10} \mathrm{H}_{16} \mathrm{~N}_{2} \mathrm{O}_{12}$ & LVOC & Yes & $1.12 \mathrm{E}-04$ & $8.30 \mathrm{E}+03$ & $7.2 \mathrm{E}+04$ \\
$\mathrm{C}_{10} \mathrm{H}_{16} \mathrm{~N}_{2} \mathrm{O}_{13}$ & ELVOC & Yes & $2.02 \mathrm{E}-04$ & $3.18 \mathrm{E}+03$ & $7.2 \mathrm{E}+04$ \\
$\mathrm{C}_{10} \mathrm{H}_{17} \mathrm{~N}_{3} \mathrm{O}_{12}$ & LVOC & Yes & $6.62 \mathrm{E}-05$ & $3.63 \mathrm{E}+04$ & $7.2 \mathrm{E}+04$ \\
$\mathrm{C}_{10} \mathrm{H}_{17} \mathrm{~N}_{3} \mathrm{O}_{13}$ & LVOC & Yes & $1.33 \mathrm{E}-04$ & $1.10 \mathrm{E}+04$ & $7.2 \mathrm{E}+04$ \\
$\mathrm{C}_{10} \mathrm{H}_{17} \mathrm{~N}_{3} \mathrm{O}_{14}$ & ELVOC & Yes & $1.87 \mathrm{E}-04$ & $7.96 \mathrm{E}+03$ & $7.2 \mathrm{E}+04$ \\
$\mathrm{C}_{10} \mathrm{H}_{17} \mathrm{~N}_{3} \mathrm{O}_{15}$ & ELVOC & Yes & $3.61 \mathrm{E}-04$ & $2.03 \mathrm{E}+03$ & $7.2 \mathrm{E}+04$ \\
$\mathrm{C}_{10} \mathrm{H}_{17} \mathrm{~N}_{3} \mathrm{O}_{16}$ & ELVOC & Yes & $5.25 \mathrm{E}-04$ & $1.10 \mathrm{E}+03$ & $7.2 \mathrm{E}+04$ \\
\hline
\end{tabular}

${ }^{a}$ estimated by the median value of $\mathrm{C}^{*}$ from different vapor pressure calculation methods used in this study 
Table S4: Average carbon oxidation state $\left(\overline{O S_{C}}\right)$ measured from ambient or different isoprene oxidation systems

$\overline{O S_{C}} \quad$ Technique $\quad$ Ref.

\section{Chamber measurements}

\section{Gas-phase products}

Isoprene $+\mathrm{NO}_{3}$

Isoprene 4-hydroxy-3-hydroperoxy

$(4,3-\mathrm{ISOPOOH})+\mathrm{OH}$

$$
-0.35 \text { to }+0.09
$$

avg. +0.10

$$
\sim-1.3
$$

$-0.31(+) /-0.25(-)^{\text {a }}$

-0.53 to -0.35

avg. +0.05

avg. -0.7

-0.5 to +1.8
$\mathrm{Br}^{-}$CIMS

$\mathrm{NO}_{3}{ }^{-} \mathrm{CIMS}$

AMS

ESI-MS

AMS

AMS

AMS

ACSM
Ref.

\begin{tabular}{|c|c|c|c|}
\hline Mexico City, US & -1.54 to +0.11 & AMS & Aiken et al., 2008 \\
\hline Amazonia & -0.9 to -0.2 & AMS & Chen et al., 2009 \\
\hline Whistler Peak, Canada & avg. -0.14 & AMS & Sun et al., 2009 \\
\hline Kaiping, China & avg. -0.54 & AMS & Huang et al., 2011 \\
\hline Melpitz, Germany & avg. $-0.47(\mathrm{su}) /-0.4(\mathrm{a}) /-0.41(\mathrm{w})^{\mathrm{b}}$ & AMS & Poulain et al., (2011) \\
\hline Hongkong, China & $\begin{array}{l}\text { avg. }-0.59(\mathrm{sp}) /-0.32(\mathrm{su}) / \\
-0.55(\mathrm{a}) /-0.54(\mathrm{w})^{\mathrm{b}}\end{array}$ & AMS & Li et al., 2015 \\
\hline Mount Wuzhi, China & avg. +0.64 & AMS & Zhu et al., 2016 \\
\hline Lake Hongze, China & avg. -0.18 & AMS & Zhu et al., 2016 \\
\hline Beijing, China & $\begin{array}{l}\text { avg. }-0.64(\mathrm{sp}) /-0.54(\mathrm{su}) / \\
-0.66(\mathrm{a}) /-0.58(\mathrm{w})^{\mathrm{b}}\end{array}$ & AMS & Hu et al., 2017 \\
\hline Houston, US & avg. -0.09 & AMS & Al-Naiema et al., 2018 \\
\hline Seoul, Korea & avg. -0.80 & AMS & Kim et al., 2018 \\
\hline Zurich, Switzerland & avg. $-0.31(\mathrm{w}) /-0.25(\mathrm{su})^{\mathrm{b}}$ & ESI-UHR-MS & Daellenbach et al., 2019 \\
\hline Hyytiälä, Finland & avg. $-0.66(2011) /-0.36(2014)^{c}$ & ESI-UHR-MS & Daellenbach et al., 2019 \\
\hline Waliguan, China & avg. +0.55 & AMS & Zhang et al., 2019 \\
\hline Yorkville, US & avg. +0.15 & $\begin{array}{l}\text { FIGAERO- } \\
\text { CIMS }\end{array}$ & Chen et al., 2020 \\
\hline Yorkville, US & avg. -0.12 & AMS & Chen et al., 2020 \\
\hline Xinglong, China & $\begin{array}{c}\text { avg. }-0.01(\mathrm{sp}) /+0.10(\mathrm{su}) / \\
0.26(\mathrm{a}) /-0.45(\mathrm{w})^{\mathrm{b}}\end{array}$ & AMS & Li et al., 2021 \\
\hline
\end{tabular}

\section{Ambient measurements}

\begin{tabular}{|c|c|c|c|}
\hline Mexico City, US & -1.54 to +0.11 & AMS & Aiken et al., 2008 \\
\hline Amazonia & -0.9 to -0.2 & AMS & Chen et al., 2009 \\
\hline Whistler Peak, Canada & avg. -0.14 & AMS & Sun et al., 2009 \\
\hline Kaiping, China & avg. -0.54 & AMS & Huang et al., 2011 \\
\hline Melpitz, Germany & avg. $-0.47(\mathrm{su}) /-0.4(\mathrm{a}) /-0.41(\mathrm{w})^{\mathrm{b}}$ & AMS & Poulain et al., (2011) \\
\hline Hongkong, China & $\begin{array}{l}\text { avg. }-0.59(\mathrm{sp}) /-0.32(\mathrm{su}) / \\
\quad-0.55(\mathrm{a}) /-0.54(\mathrm{w})^{\mathrm{b}}\end{array}$ & AMS & Li et al., 2015 \\
\hline Mount Wuzhi, China & avg. +0.64 & AMS & Zhu et al., 2016 \\
\hline Lake Hongze, China & avg. -0.18 & AMS & Zhu et al., 2016 \\
\hline Beijing, China & $\begin{array}{l}\text { avg. }-0.64(\mathrm{sp}) /-0.54(\mathrm{su}) / \\
\quad-0.66(\mathrm{a}) /-0.58(\mathrm{w})^{\mathrm{b}}\end{array}$ & AMS & Hu et al., 2017 \\
\hline Houston, US & avg. -0.09 & AMS & Al-Naiema et al., 2018 \\
\hline Seoul, Korea & avg. -0.80 & AMS & Kim et al., 2018 \\
\hline Zurich, Switzerland & avg. $-0.31(\mathrm{w}) /-0.25(\mathrm{su})^{\mathrm{b}}$ & ESI-UHR-MS & Daellenbach et al., 2019 \\
\hline Hyytiälä, Finland & avg. $-0.66(2011) /-0.36(2014)^{c}$ & ESI-UHR-MS & Daellenbach et al., 2019 \\
\hline Waliguan, China & avg. +0.55 & AMS & Zhang et al., 2019 \\
\hline Yorkville, US & avg. +0.15 & $\begin{array}{l}\text { FIGAERO- } \\
\text { CIMS }\end{array}$ & Chen et al., 2020 \\
\hline Yorkville, US & avg. -0.12 & AMS & Chen et al., 2020 \\
\hline Xinglong, China & $\begin{array}{c}\text { avg. }-0.01(\mathrm{sp}) /+0.10(\mathrm{su}) / \\
0.26(\mathrm{a}) /-0.45(\mathrm{w})^{\mathrm{b}}\end{array}$ & AMS & Li et al., 2021 \\
\hline
\end{tabular}

Aiken et al., 2008

Nguyen et al., 2010

Chhabra et al., 2010

Krechmer et al., 2015

Lambe et al., 2015

Wang and Ruiz, 2018

\section{Ambient organic aerosol}


Oklahoma, US

\section{Ambient aerosol fractions}

Hydrocarbon-like OA (HOA)

Oxygenated OA type I (OOA-I)

Oxygenated OA type II (OOA-II)

Daytime more oxidized OA

Daytime ON-rich OA

Morning less oxidized OA

Afternoon less oxidized OA

Nighttime ON-rich OA

OOA-I

OOA-II

Isoprene-epoxydiol-derived SOA (IEPOX SOA)

HOA

Cooking-influenced less-oxidized

oxygenated OA

More-oxidized oxygenated OA avg. +0.289 (sp)/ -0.34 (su) ${ }^{\text {b }}$

$$
\begin{gathered}
-1.7 \text { to }-1.6 \\
-0.5 \text { to } 0.0 \\
+0.5 \text { to }+0.9
\end{gathered}
$$

avg. +0.50

avg. +0.35

avg. -0.13

avg. +0.04

avg. +0.13

avg. $+0.14(\mathrm{sp}) /-0.099(\mathrm{su})^{\mathrm{b}}$

avg. -0.315 (sp)/ -0.264 (su) ${ }^{\text {b }}$

avg. $+1.606(\mathrm{sp}) /-0.096(\mathrm{su})^{\mathrm{b}}$

avg. -1.91

avg. -0.35

avg. +1.27

avg. -0.043
AMS

Liu et al., 2021

AMS

Aiken et al., 2008

AMS

Aiken et al., 2008

AMS

Aiken et al., 2008

FIGAERO-

CIMS

Chen et al., 2020

FIGAERO-

CIMS

Chen et al., 2020

FIGAERO-

CIMS

Chen et al., 2020

FIGAERO-

CIMS

Chen et al., 2020

FIGAERO-

CIMS

Chen et al., 2020

AMS

Liu et al., 2021

AMS

Liu et al., 2021

AMS

Liu et al., 2021

AMS

Al-Naiema et al., 2018

AMS

Al-Naiema et al., 2018

AMS

Al-Naiema et al., 2018

Massoli et al., 2018

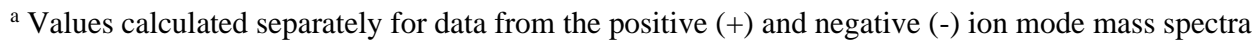

${ }^{b}$ Values calculated separately for data collected in spring (sp), summer (su), autumn (a) and winter (w).

${ }^{c}$ Values calculated for data collected in 2011 and 2014 


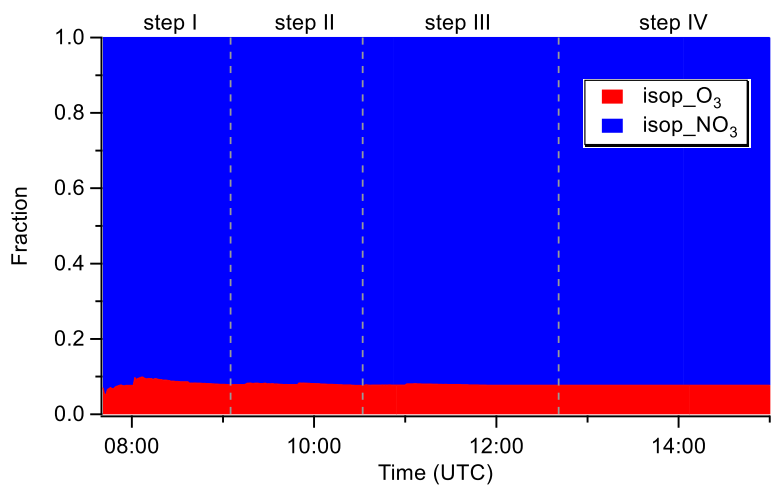

Figure S1: Fraction of isoprene consumed by $\mathrm{O}_{3}$ and $\mathrm{NO}_{3}$ calculated from measurements. The amount of isoprene consumed by $\mathrm{O}_{3}$ was calculated from the measured concentrations of $\mathrm{O}_{3}$ and isoprene, and that consumed by $\mathrm{NO}_{3}$ was calculated from total isoprene losses (from isoprene measurements) subtracting losses due to dilution and reaction with $\mathrm{O}_{3}$. Isoprene losses due to reaction with $\mathrm{OH}$ could not be included here, because the $\mathrm{OH}$ concentration was below the detection limit. However, according to model calculations $\mathrm{OH}$ contributed about $100 \%$ to the isoprene consumption (Vereecken et al., 2021). 

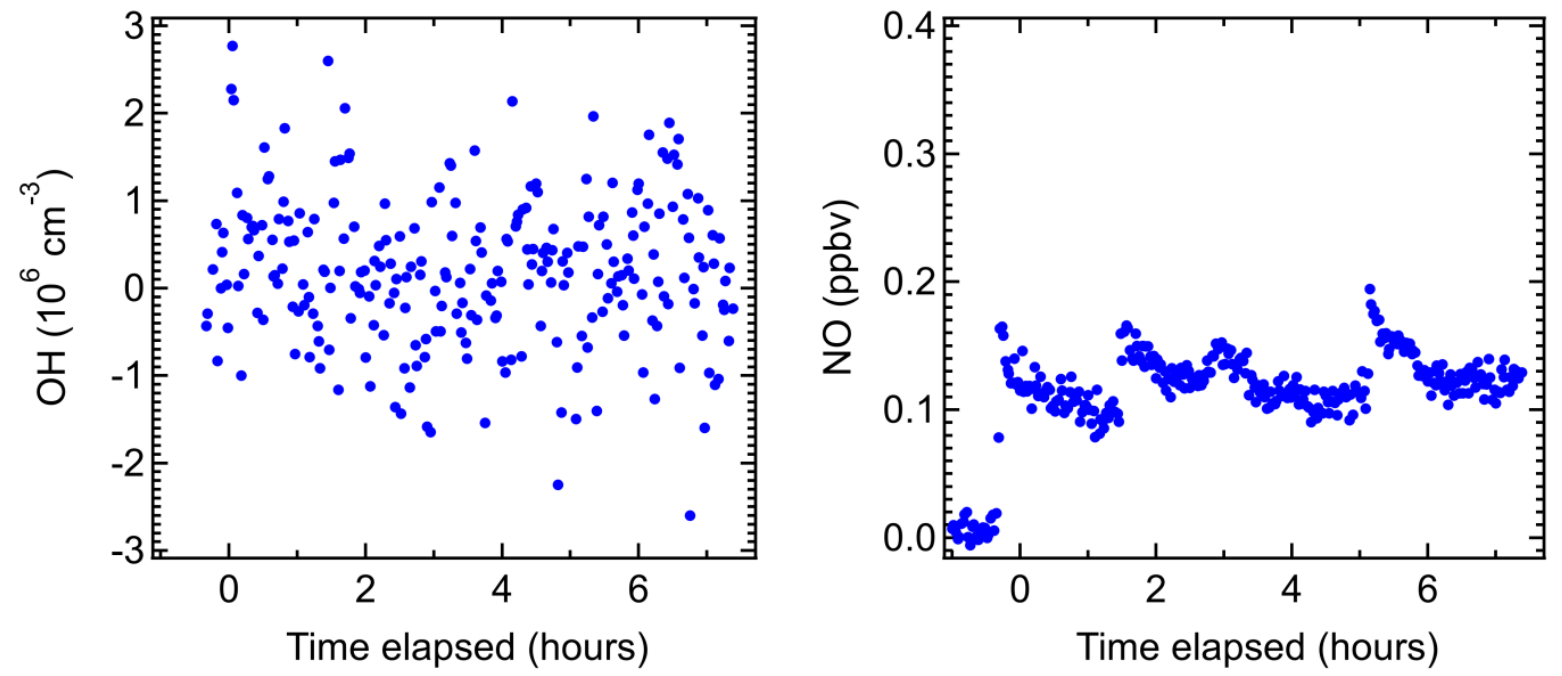

Figure S2: Concentrations of $\mathrm{OH}$ radical and NO during the isoprene-NO3 experiment on 08 August, 2018. The OH concentration was measured by a laser-induced fluorescence (LIF) spectroscopy, and the NO mixing ratio was detected by a chemiluminescence analyzer. It should be pointed out that there was no NO in the chamber under dark condition, because the lifetime of NO would be very short under high $\mathrm{O}_{3}$ condition. The non-zero values of NO are measurement artefacts due to the relatively high $\mathrm{NO}_{2}$ concentration. 


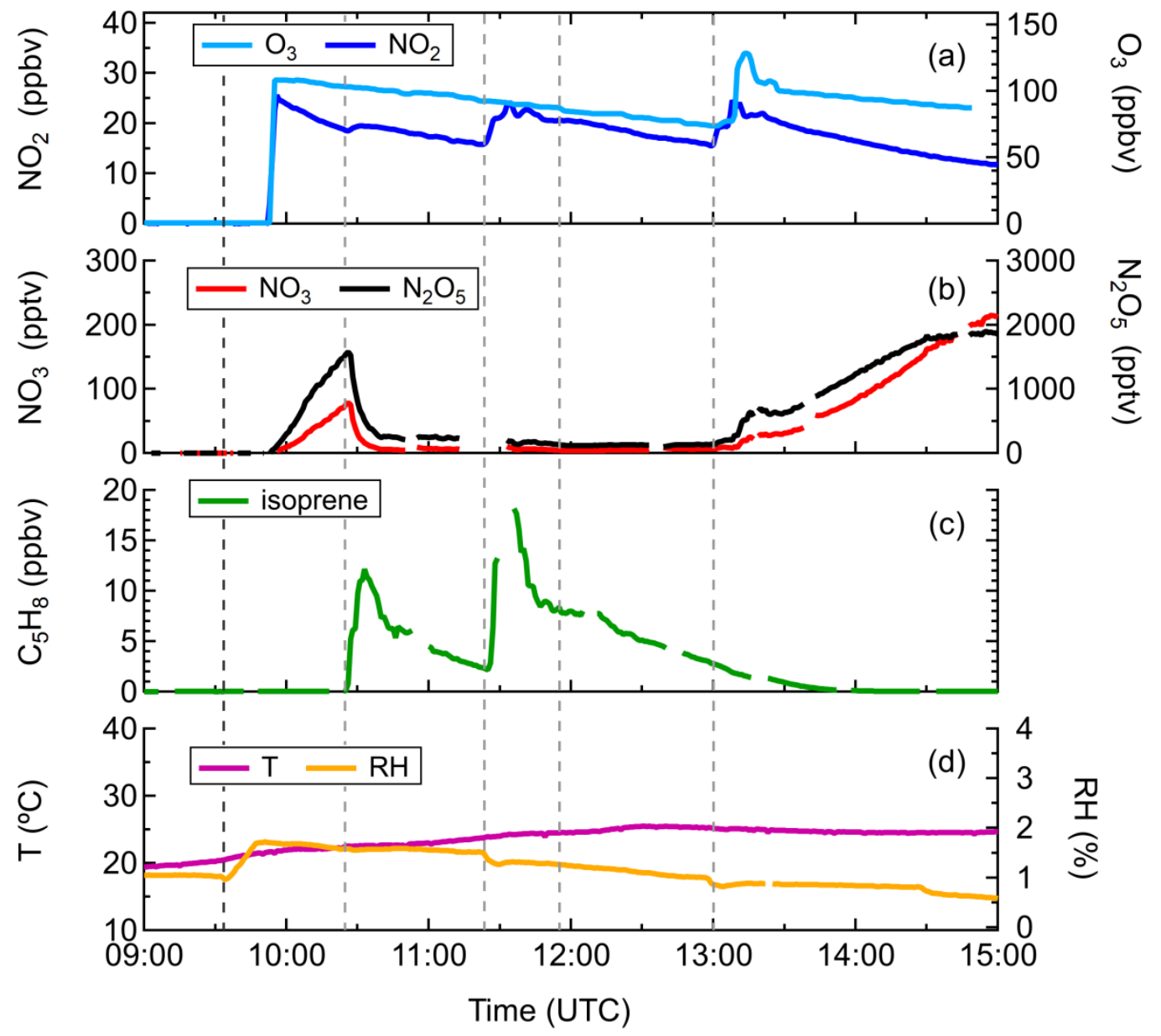

Figure S3: Measurements of (a) $\mathrm{O}_{3}$ and $\mathrm{NO}_{2}$, (b) $\mathrm{NO}_{3}$ and $\mathrm{N}_{2} \mathrm{O}_{5}$, (c) isoprene and (d) temperature and relative humidity in the chamber during the experiment on 14 August, 2018. 

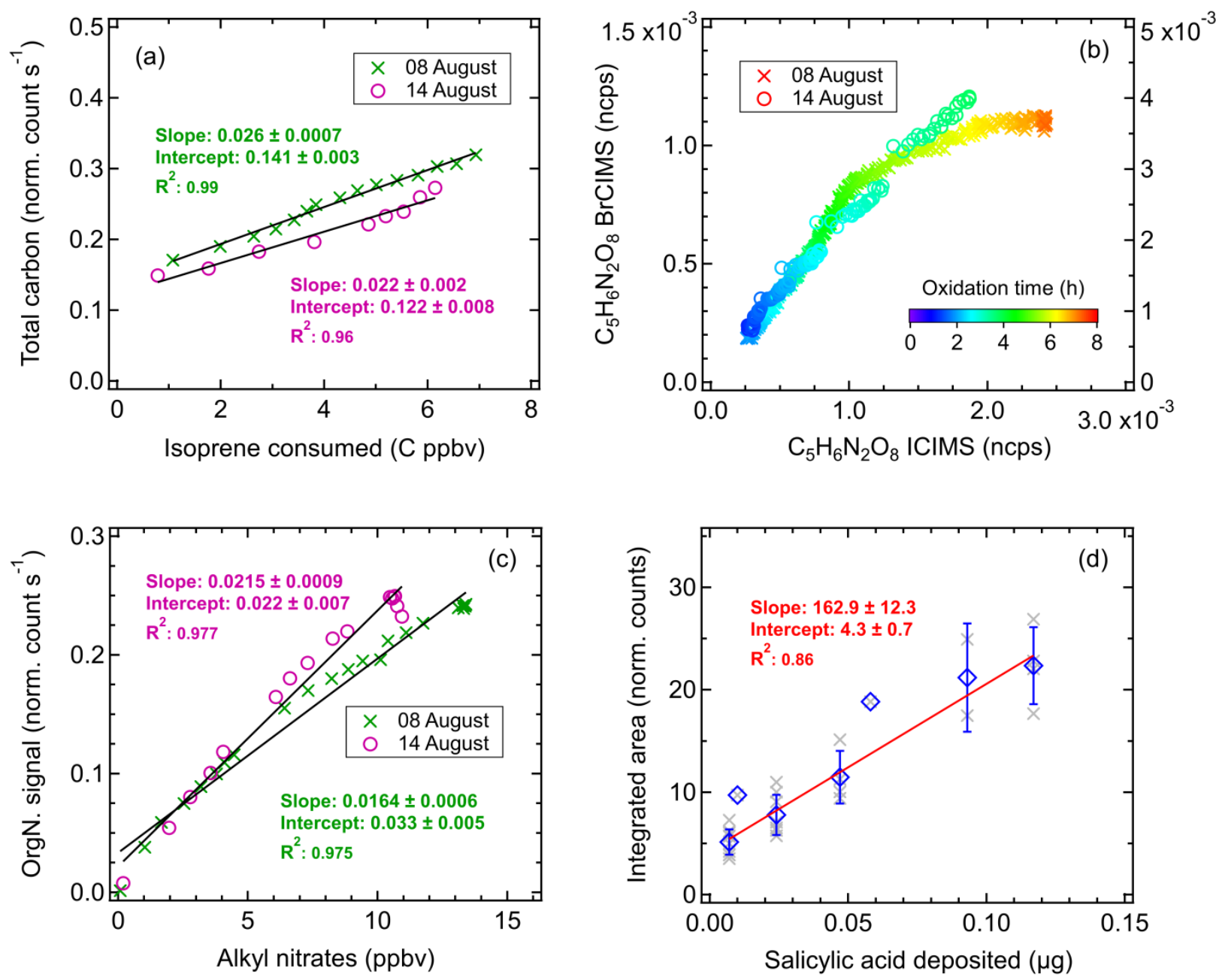

Figure S4: (a) Total carbon detected by Br-CIMS versus isoprene consumed on 08 and 14 August, 2018. The sensitivity of CIMS for total carbon is determined by the slope of linear fit. The data have been corrected for dilution and wall losses. (b) Comparison of $\mathrm{C}_{5} \mathrm{H}_{6} \mathrm{~N}_{2} \mathrm{O}_{8}$ measurements by $\mathrm{Br}^{-} \mathrm{CIMS}$ and $\mathrm{I}^{-} \mathrm{CIMS}$. (c) Organonitrates measured by $\mathrm{Br}^{-} \mathrm{CIMS}^{-}$plotted against gas-phase alkyl nitrates measured by TDCRDS. The bulk sensitivity for organonitrates is determined by the slope of linear fit. (d) Calibration results of Br- CIMS for salicylic acid. 

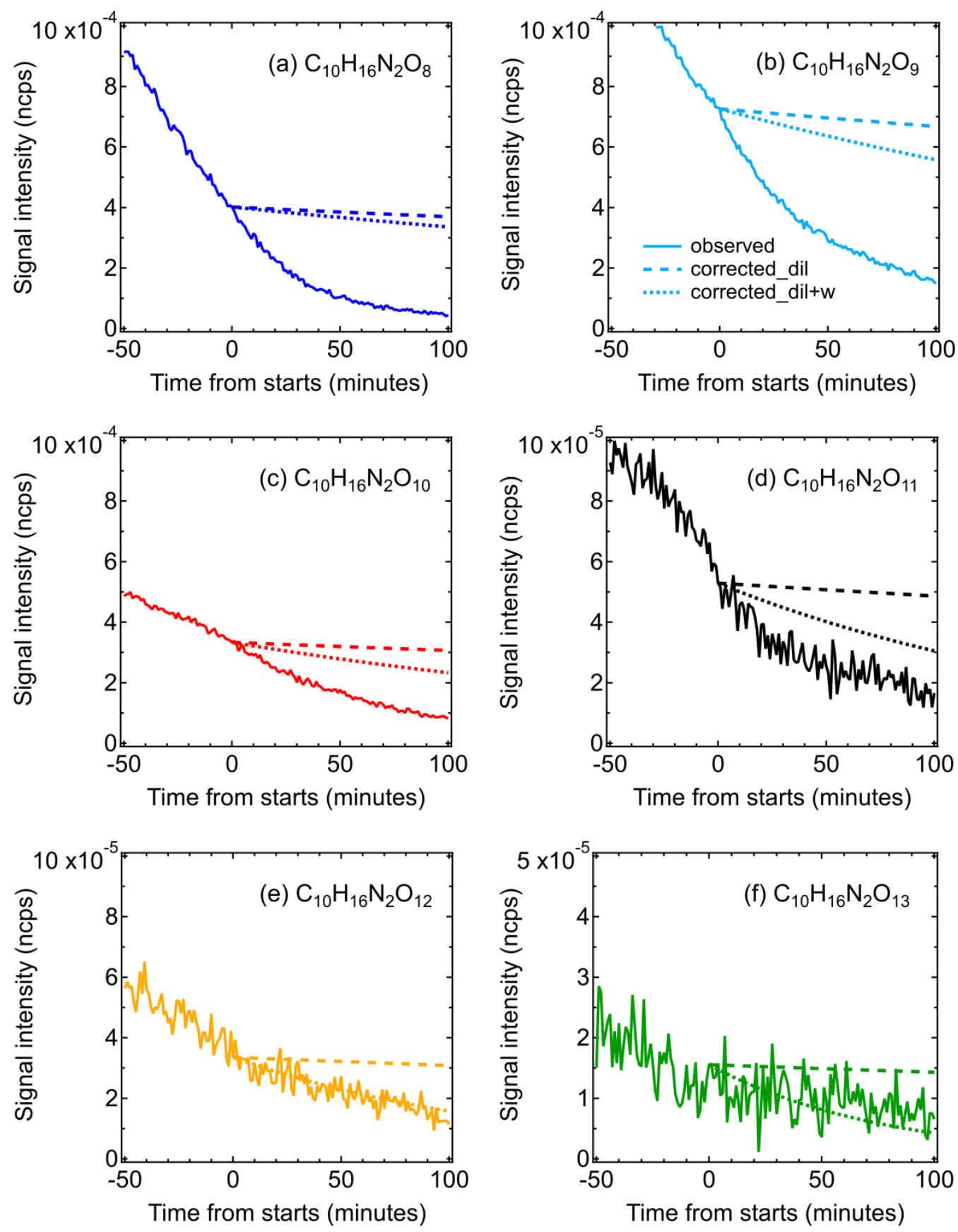

Figure S5: Comparison of the observed and predicted time evolution of $2 \mathrm{~N}$-dimers in step IV (only dilution or dilution and wall losses was considered). The time when the last injection of $\mathrm{O}_{3}$ and $\mathrm{NO}_{2}$ (without isoprene) occurred is set as zero. 


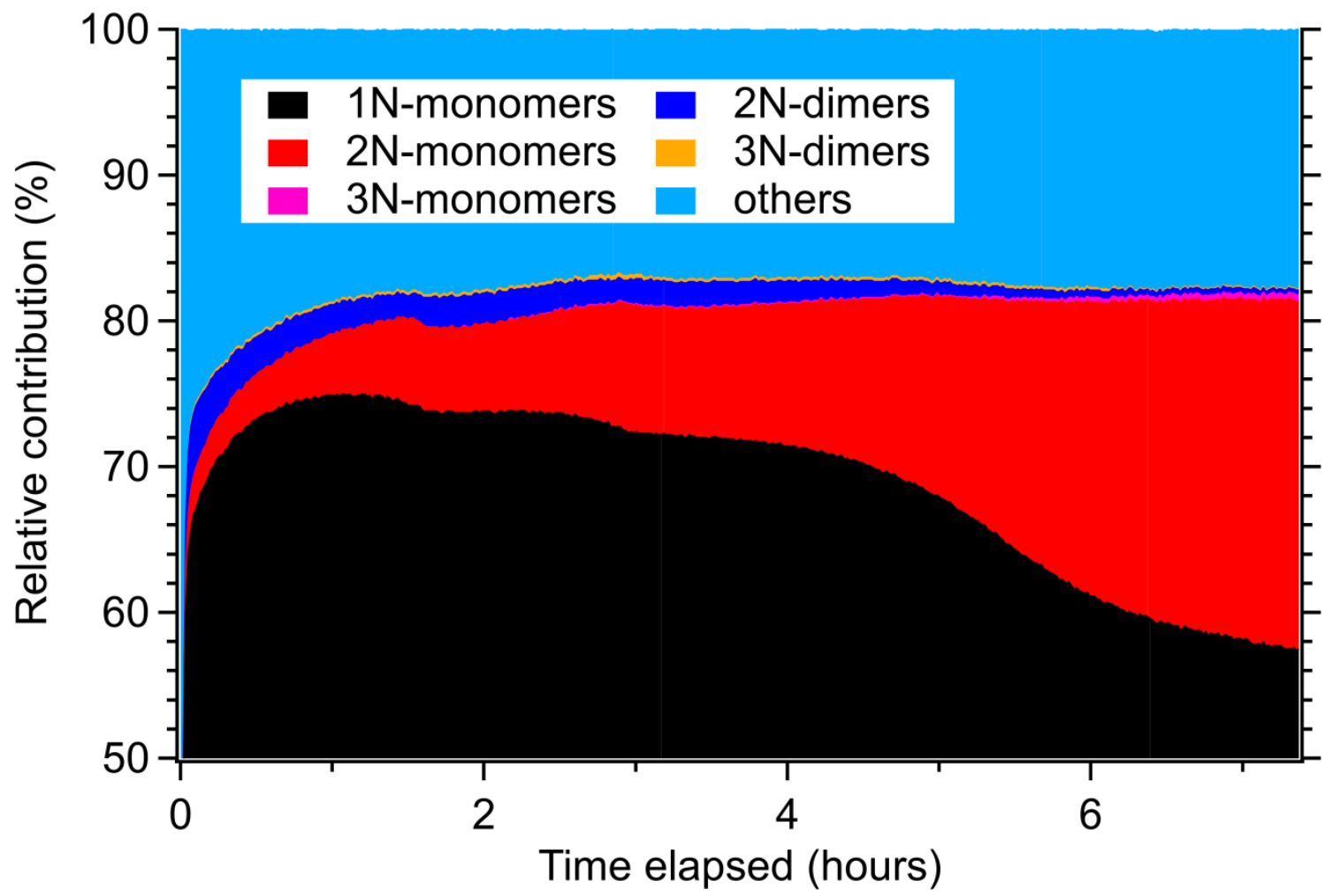

Figure S6: Time evolution of the relative contributions of different chemical groups measured by Br-CIMS (only organic ions were counted for analysis). 'Others' refers to $\mathrm{CHO}$ compounds without containing nitrogen atoms (e.g., $\mathrm{C}_{5} \mathrm{H}_{8} \mathrm{O}_{2}$ and $\left.\mathrm{C}_{5} \mathrm{H}_{8} \mathrm{O}_{3}\right)$. 


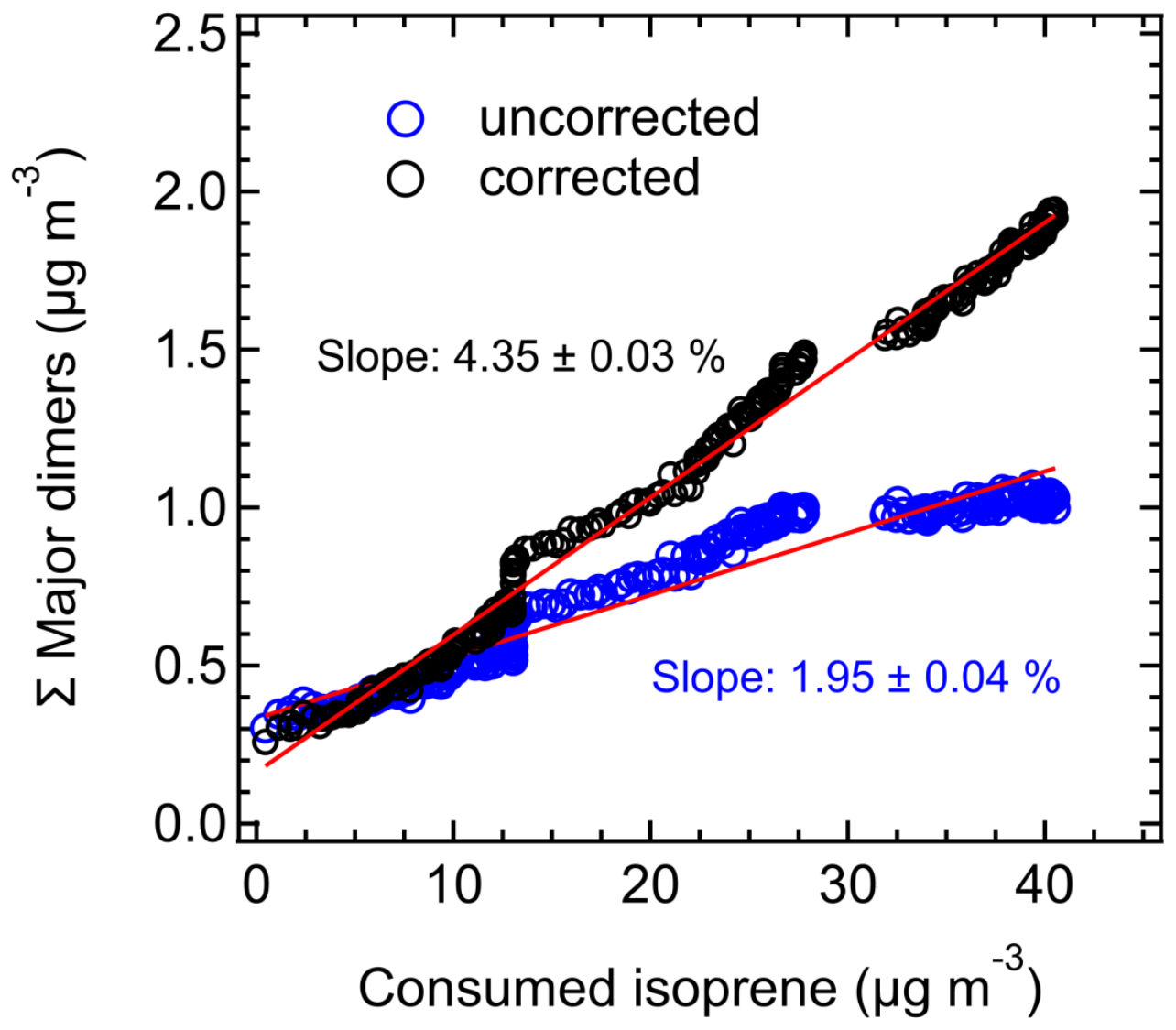

Figure S7: Major dimers mass as a function of consumed isoprene. Fitting a straight line to the data yields slopes of $1.95 \pm$ $0.04 \%$ and $4.35 \pm 0.03 \%$ for the uncorrected data and wall and dilution corrected data, respectively. The errors are the statistical errors of the fits. Wall loss corrections are shown in Table S3. Assuming all the dimers in the LVOC and ELVOC range can condense onto particles, producing SOA, we estimate a mass yield of about $5 \% \pm 1.6 \%$. The relative uncertainty of SOA yield here was estimated to be $32 \%$ by using error propagation, which includes the uncertainty of the isoprene consumption concentration $(\sim 10 \%)$, the uncertainty of the alkyl nitrate concentration $(\sim 10 \%)$, the uncertainty of dimer content $(\sim 20 \%)$, and the uncertainty of estimated instrument sensitivity for organonitrates $(\sim 22 \%)$. 


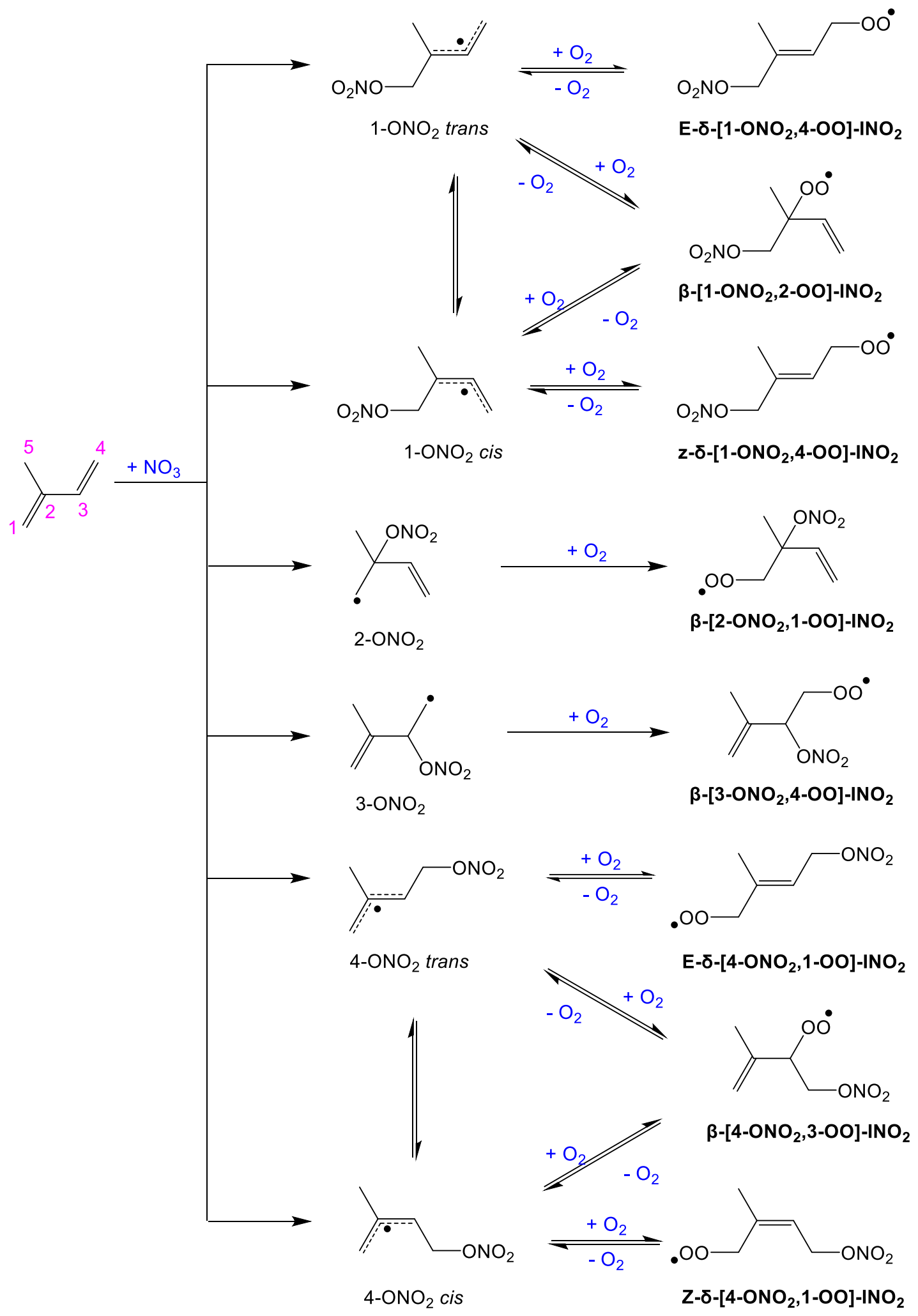

Scheme S1: Formation of isoprene nitrooxy peroxy radicals $\left(\mathrm{INO}_{2}\right)$ from $\mathrm{NO}_{3}$-initiated oxidation with subsequent $\mathrm{O}_{2}$ addition. 
Scheme S2 - S4 serve to show which formula species can be expected in principle accoridng to the understanding of peroxy and alkoxy chemistry under consideration of intramolecular H-shifts and autoxoidation processes.
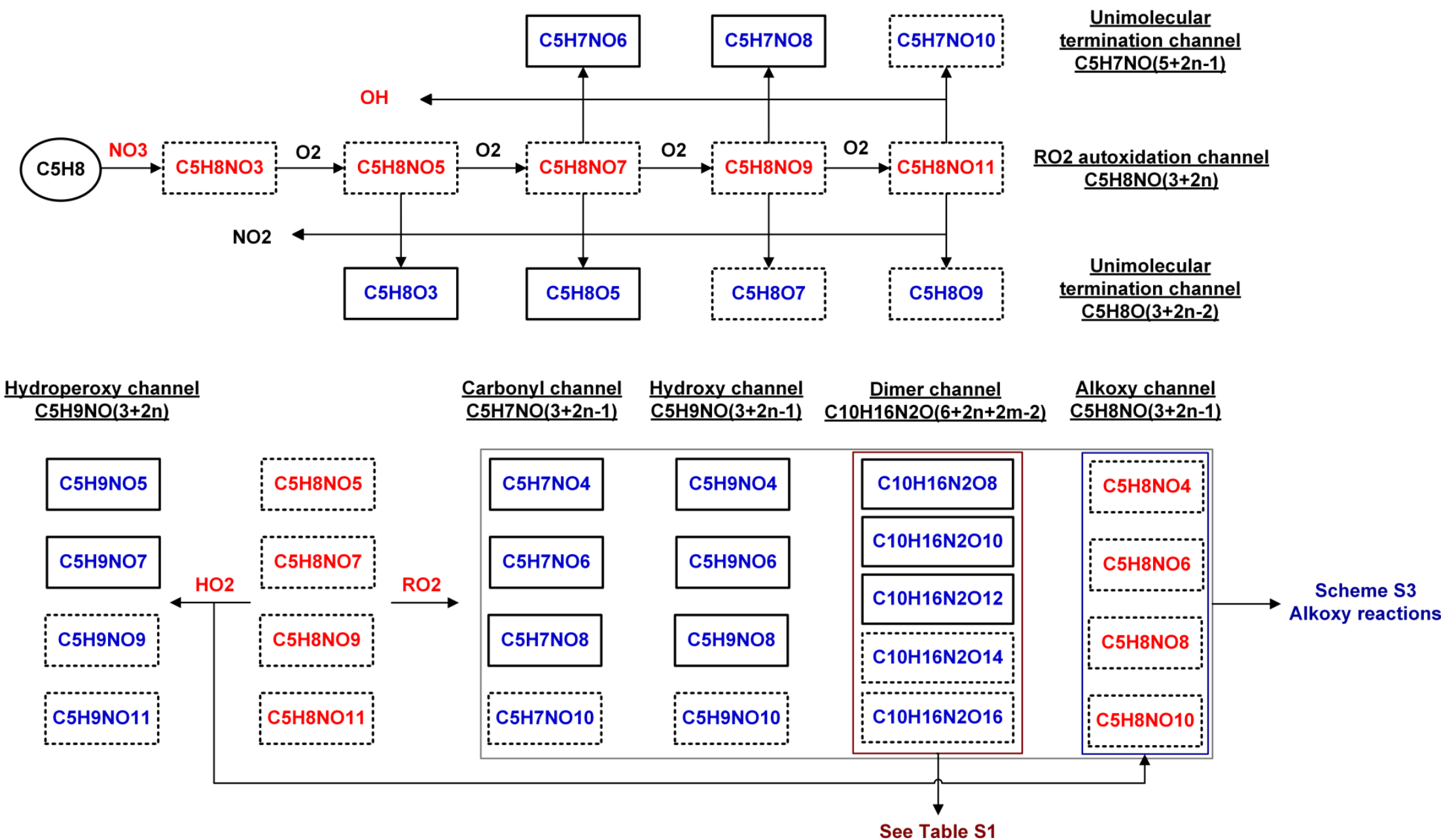

Scheme S2. Proposed first-generation reaction pathways of isoprene-NO $\mathrm{N}_{3}$ and the corresponding products. (n $\geq 1$, number of autoxidation steps). Closed-shell products are presented in blue, while radicals are presented in red. Compounds with the given molecular formula in solid boxes have been detected by Br- CIMS during the experiments, while those in dashed boxes have not. 

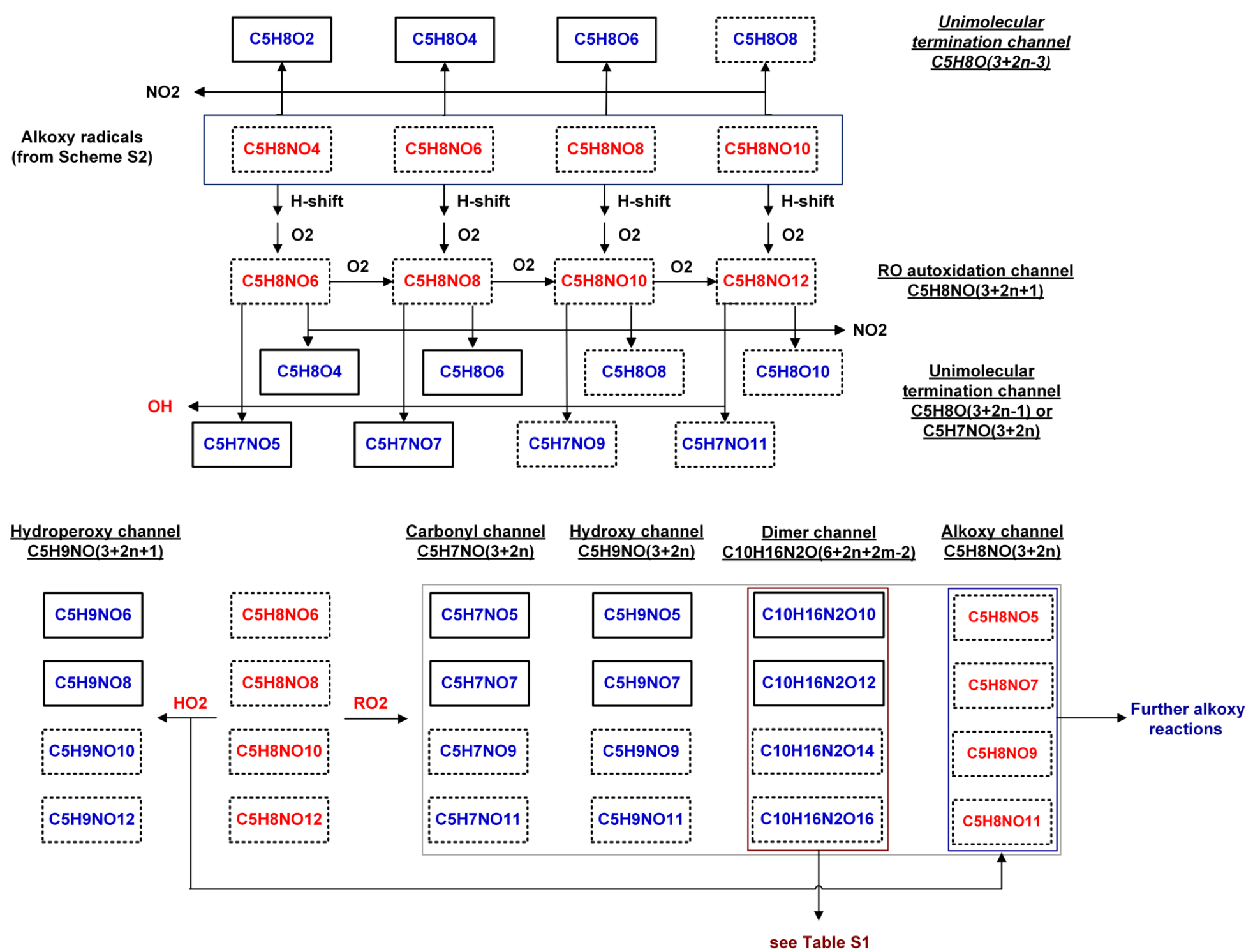

Scheme S3: Proposed reaction pathways of alkoxy radicals (formed from $\mathrm{RO}_{2}$ alkoxy channel) and the corresponding products (n $\geq 1$, number of autoxidation steps), Closed-shell products are presented in blue, while radicals are presented in red. Compounds with the given molecular formula in solid boxes have been detected by Br CIMS during the experiments, while those in dashed boxes have not. 


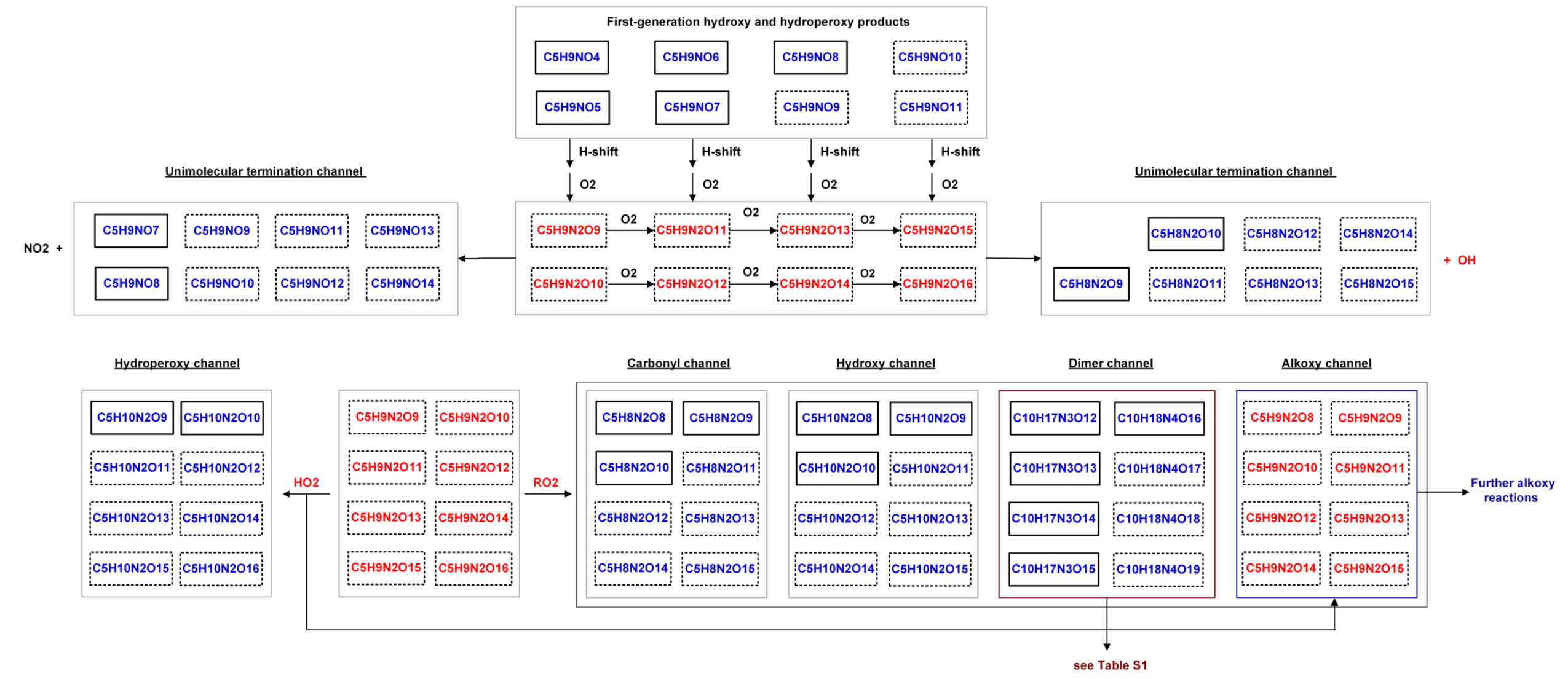

Scheme S4: Proposed second-generation reaction pathways of isoprene- $\mathrm{NO}_{3}$ and the corresponding products. The subsequent reactions of alkoxy radicals formed in this process are similar to those shown in Scheme S4, therefore not treated further here. Closed-shell products are presented in blue, while radicals are presented in red. Compounds with the given molecular formula in solid boxes have been detected by $\mathrm{Br}^{-} \mathrm{CIMS}$ during the experiments, while those in dashed boxes have not. 
Scheme S5-S13 are exemplified realizations of reaction pathways shown in Scheme S2-S4 with the purpose to assess possible functionalities of compounds with the given molecular formula. They are used to calculate the range of vapor pressures covered by the observed formula compounds.

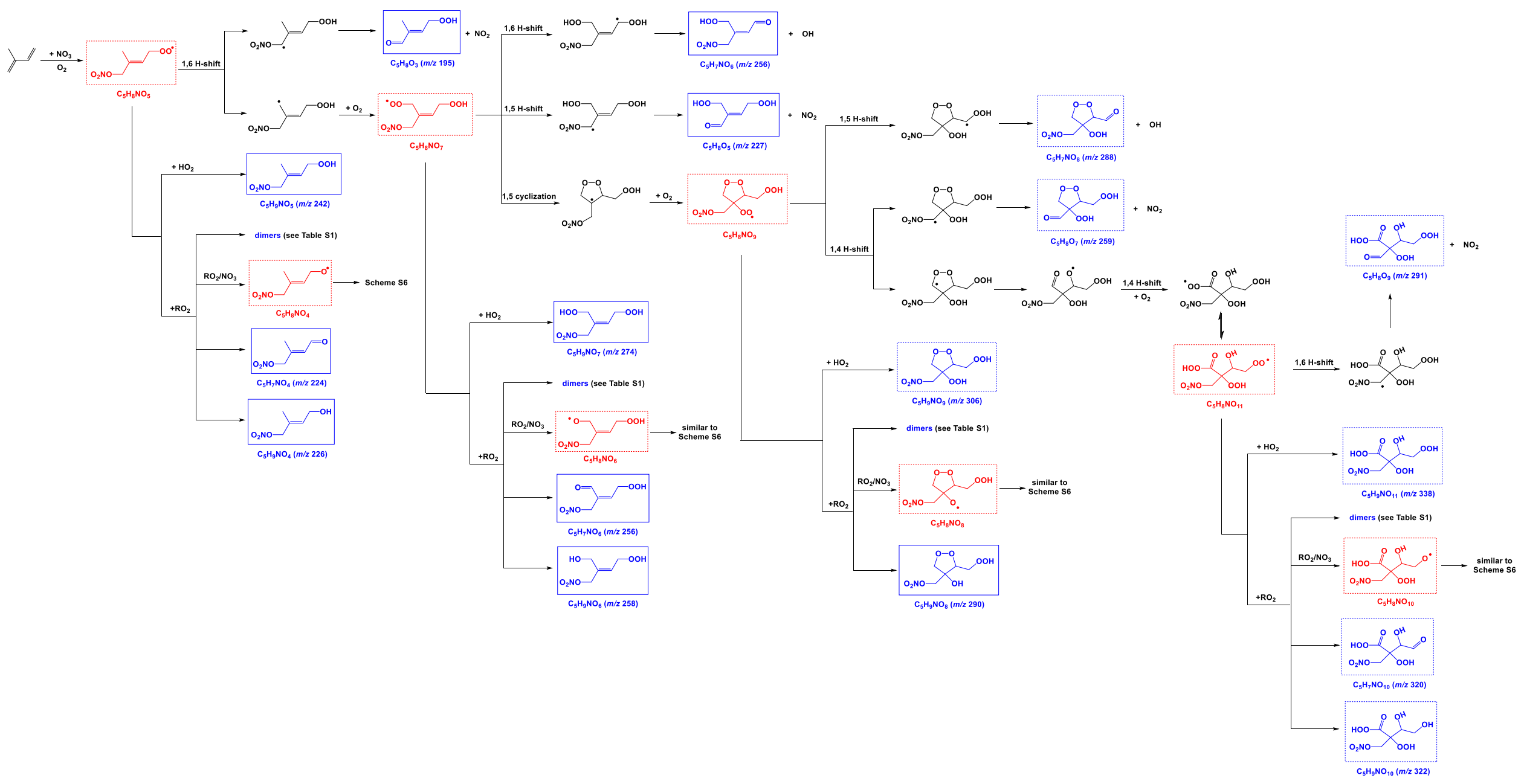

Scheme S5: General reactions and major gas-phase products formed following addition of $\mathrm{NO}_{3}$ to isoprene. Only one situation is presented, so other isomers are possible. Compounds in blue are the major closed-shell products formed during the reaction, while those in red are major intermediates. Compounds with the given molecular formula in solid boxes have been detected by CIMS as Br- adducts at the indicated $m / z$ values, while those in dashed boxes have not. 


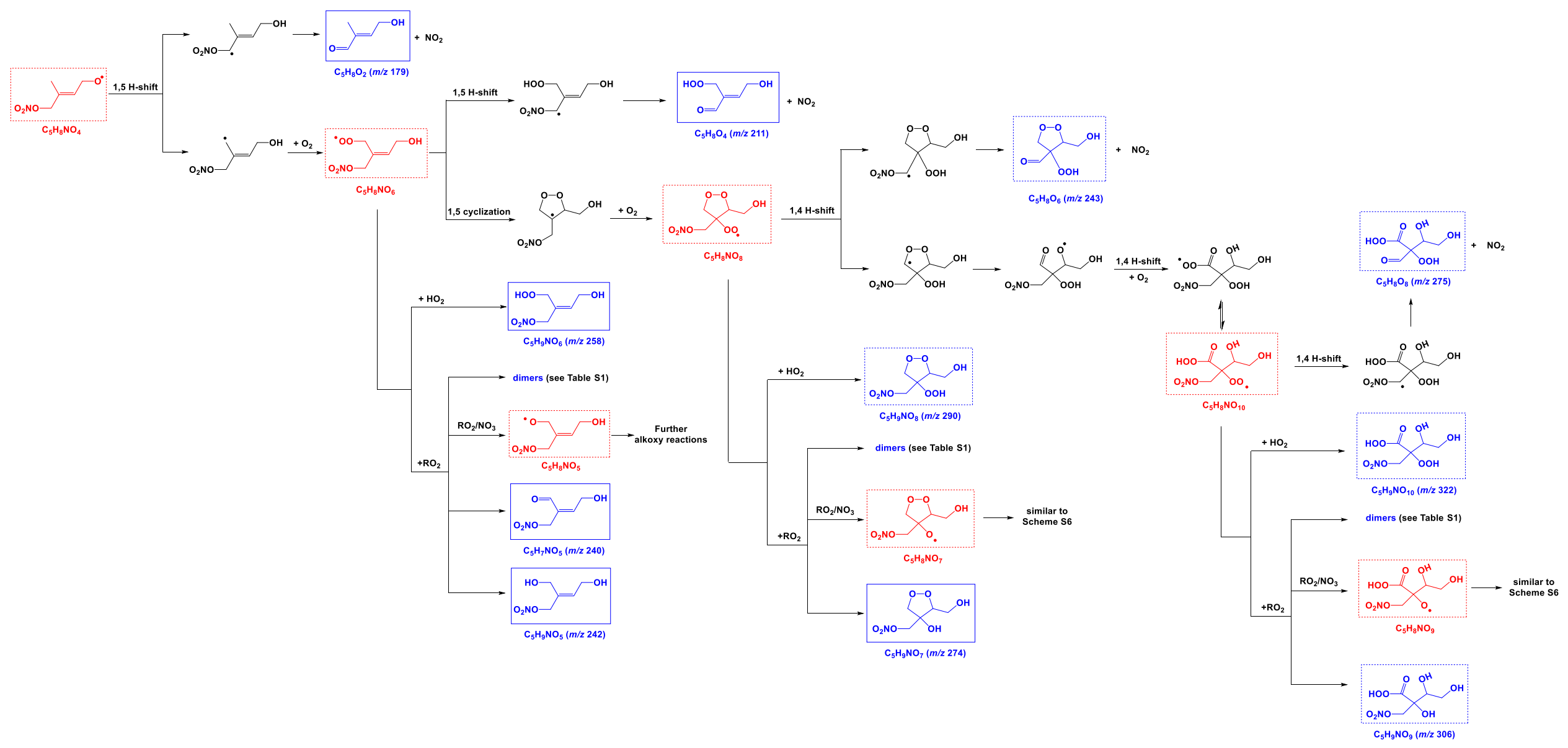

Scheme S6: General reactions and major products formed from rearrangement (H-shift) of the $\mathrm{C}_{5} \delta$-[1,4]-nitrooxy alkoxy radical. Other isomers are possible. Compounds in blue are the major closed-shell products formed during the reaction, while those in red are major intermediates. Compounds with the given molecular formula in solid boxes have been detected by CIMS as $\mathrm{Br}^{-}$adducts at the indicated $\mathrm{m} / \mathrm{z}$ values, while those in dashed boxes have not. 

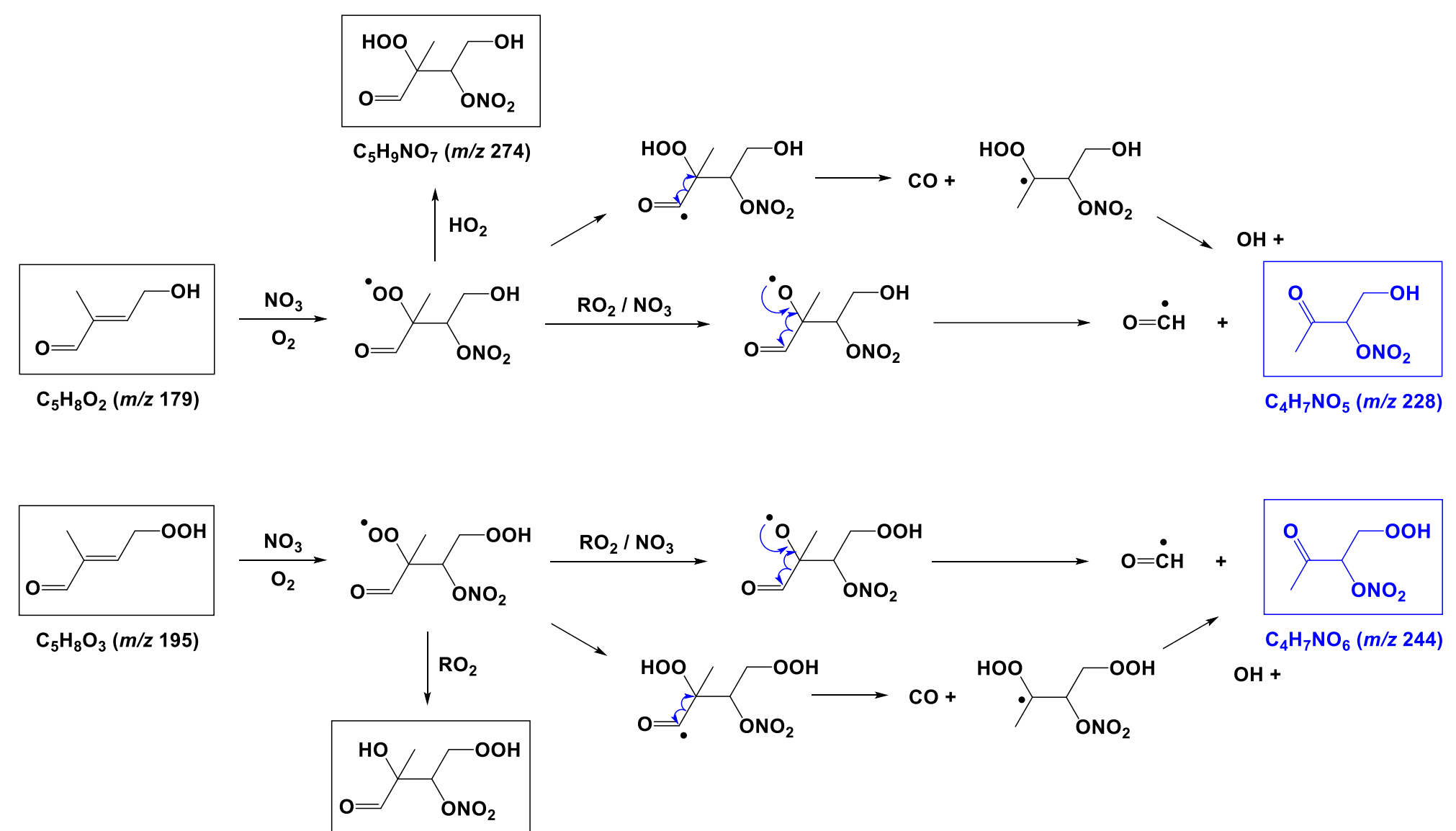

$\mathrm{C}_{5} \mathrm{H}_{9} \mathrm{NO}_{7}(\mathrm{~m} / \mathrm{z} 274)$

Scheme S7: Proposed formation mechanism of $\mathrm{C}_{4}$ carbonyl nitrates $\left(\mathrm{C}_{4} \mathrm{H}_{7} \mathrm{NO}_{5}\right.$ and $\left.\mathrm{C}_{4} \mathrm{H}_{7} \mathrm{NO}_{6}\right)$ from further oxidation of first-generation $\mathrm{C}_{5}$ carbonyl products. Other isomers are possible. Compounds with the given molecular formula in boxes are closed-shell products detected by CIMS at the indicated $m / z$ values. 


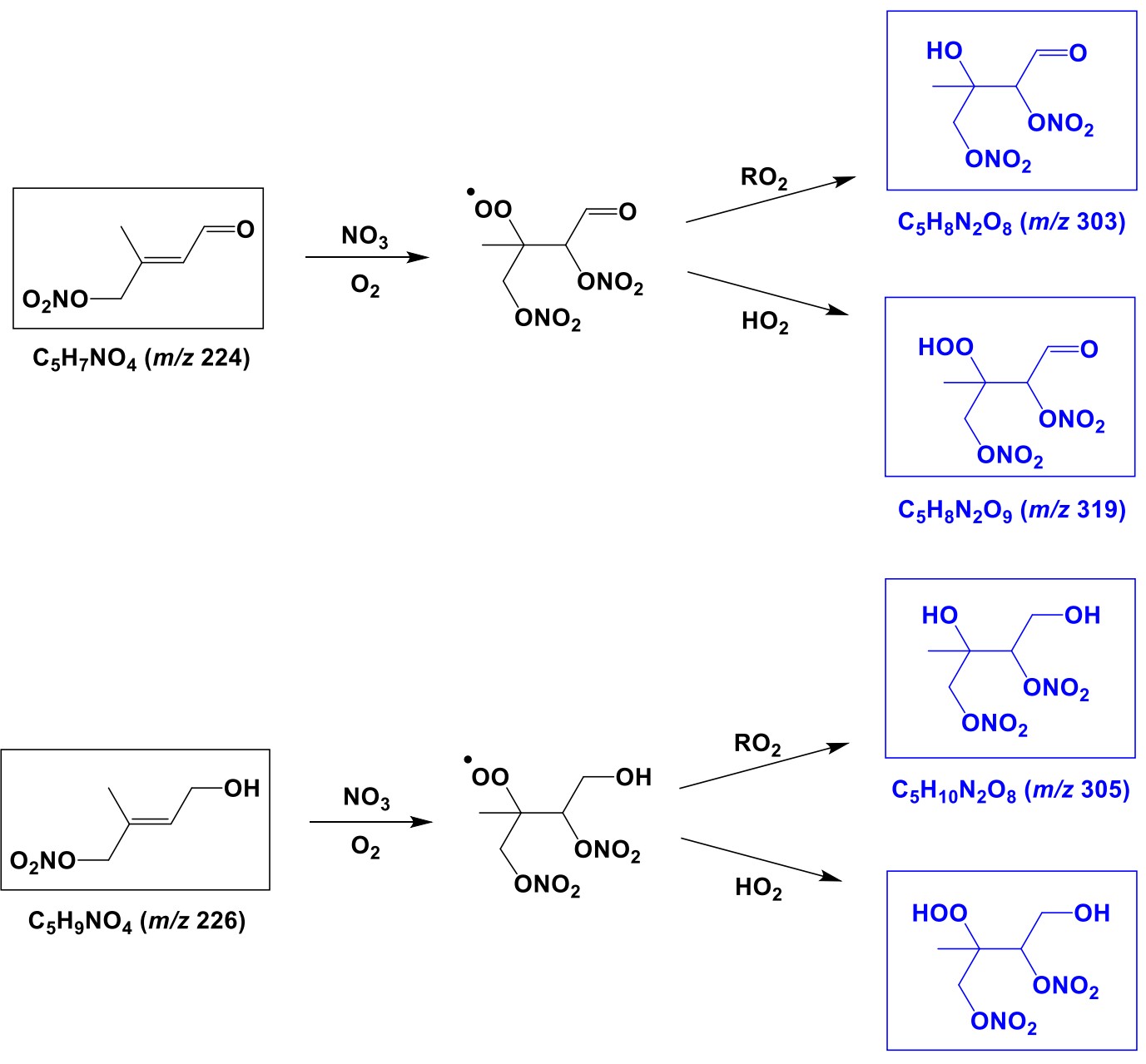

$\mathrm{C}_{5} \mathrm{H}_{10} \mathrm{~N}_{2} \mathrm{O}_{9}(\mathrm{~m} / \mathrm{z} 321)$

Scheme S8: Proposed formation mechanism of second-generation $\mathrm{C}_{5}$ dinitrates. Here the major compounds $\mathrm{C}_{5} \mathrm{H}_{8,10} \mathrm{~N}_{2} \mathrm{O}_{8,9}$ are taken as examples for illustration. Other isomers are possible. Compounds with the given molecular formula in boxes are closed-shell products detected by CIMS at the indicated $\mathbf{m} / \mathbf{z}$ values. 


\section{$\underline{\mathrm{R}} \equiv \underline{\mathrm{H}}, \underline{\mathrm{OH}}$ or $\underline{\mathrm{OOH}}$}

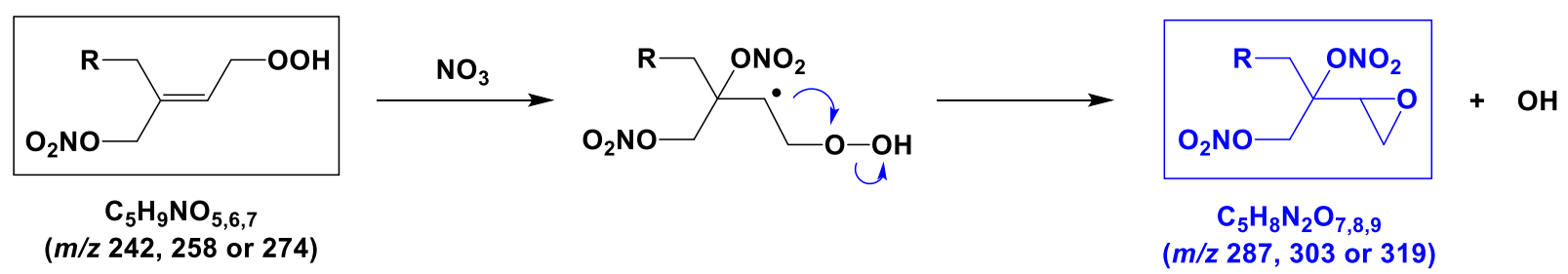

\section{$\underline{\mathrm{R}^{\prime}} \equiv \underline{\mathrm{OH}}$ or $\underline{\mathrm{OOH}}$}

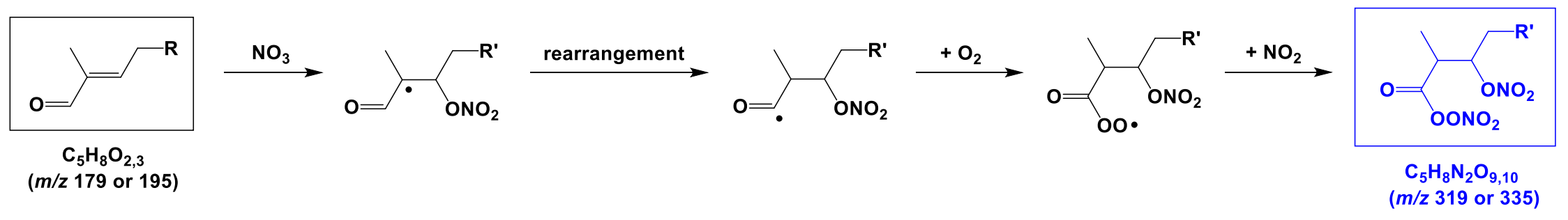

Scheme S9: Proposed formation of dinitrooxy epoxides (upper panel) and petroxyacetyl nitrates (lower panel) from second-generation oxidation by NO3 with subsequent rearrangement. Other isomers are possible. Compounds with the given molecular formula in boxes are closed-shell products detected by CIMS at the indicated m/z values. 

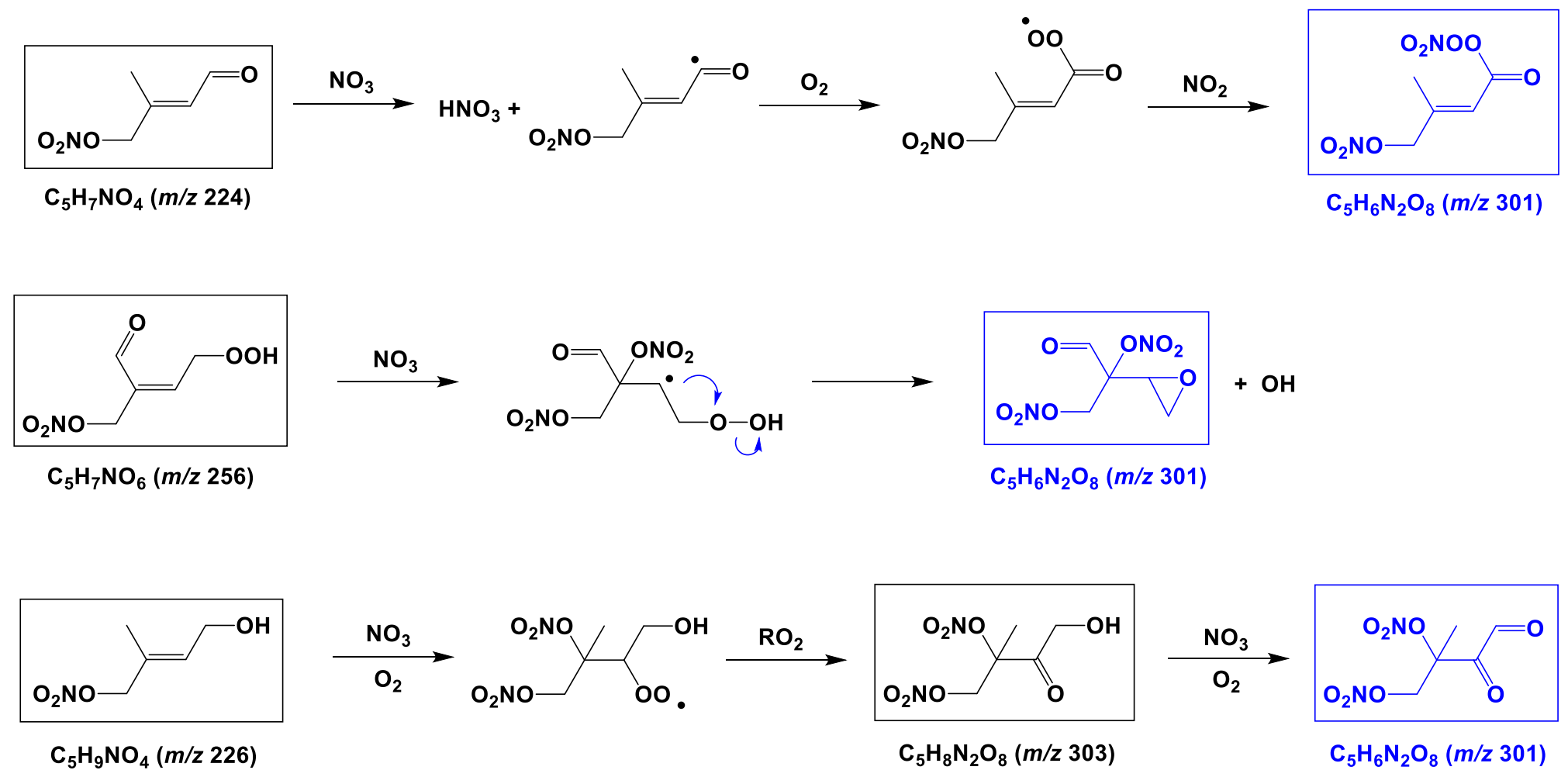

Scheme S10: Possible formation pathways of $\mathrm{C}_{5} \mathrm{H}_{6} \mathrm{~N}_{2} \mathrm{O}_{8}$. Other isomers are possible. $\mathrm{H}$-abstraction channel is adapted from MCM v3.3.1. Compounds with the given molecular formula in boxes are closed-shell products detected by CIMS at the indicated $\mathrm{m} / \mathrm{z}$ values. 


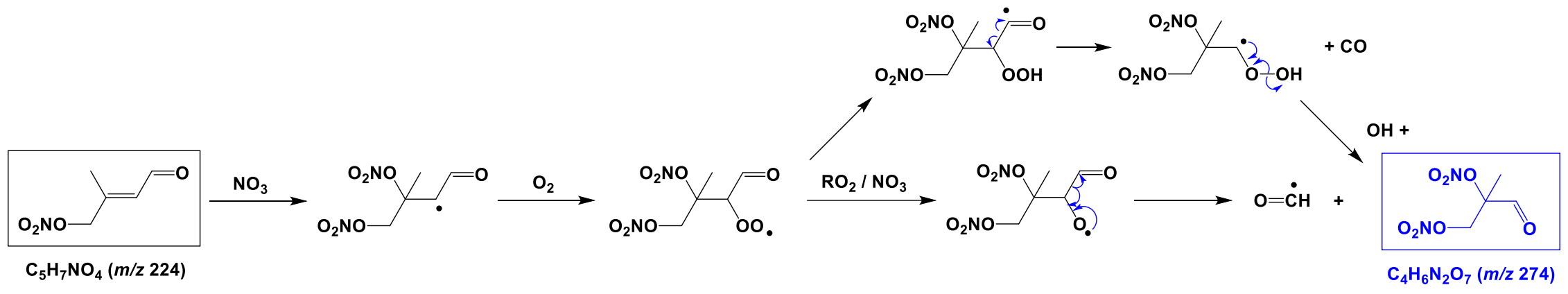

Scheme S11: Possible formation pathways of $\mathrm{C}_{4} \mathrm{H}_{6} \mathrm{~N}_{2} \mathrm{O}_{7}$. Other isomers are possible. Compounds with the given molecular formula in boxes are closed-shell products detected by CIMS at the indicated $\mathrm{m} / \mathrm{z}$ values. 


$$
\begin{aligned}
& \underline{\mathrm{R}}_{1} \equiv \underline{\mathrm{H}}, \underline{\mathrm{OH}} \\
& \underline{\mathrm{R}}_{2} \equiv \underline{\mathrm{OH}}, \underline{\mathrm{OOH}}
\end{aligned}
$$

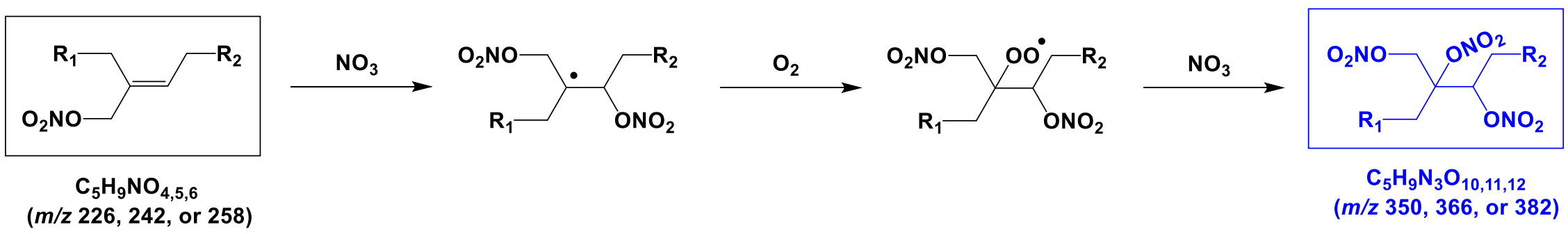

Scheme S12: Formation of trinitrates through further oxidation of the first-generation products by NOz. Other isomers are possible. Compounds with the given molecular formula in boxes are closed-shell products detected by CIMS at the indicated $\mathrm{m} / \mathrm{z}$ values. 
$2 \mathrm{~N}$-, 3N-, 4N-dimers

$\mathbf{R} / \mathbf{R}^{\prime}=\mathrm{H}, \mathrm{OH}, \mathrm{OOH}$

$\mathbf{R}_{1} / \mathbf{R}_{1}{ }^{\prime}=\mathrm{H}, \mathrm{OH}$

$\mathbf{R}_{\mathbf{2}} / \mathbf{R}_{\mathbf{2}}^{\prime}=\mathrm{OH}, \mathrm{OOH}$

$\mathrm{R}_{3} \quad=\mathrm{OH}, \mathrm{OOH}$

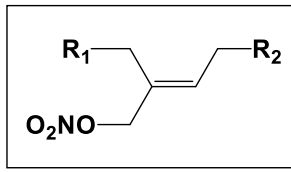

$\mathrm{C}_{5} \mathrm{H}_{9} \mathrm{NO}_{4,5,6}$

$(m / z 226,242$, or 258$)$
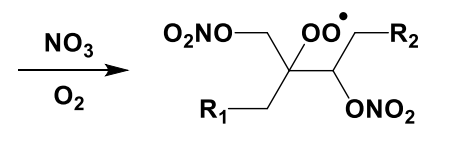

$\mathrm{ONO}_{2}^{\mathrm{O}_{2} \mathrm{NO}}$
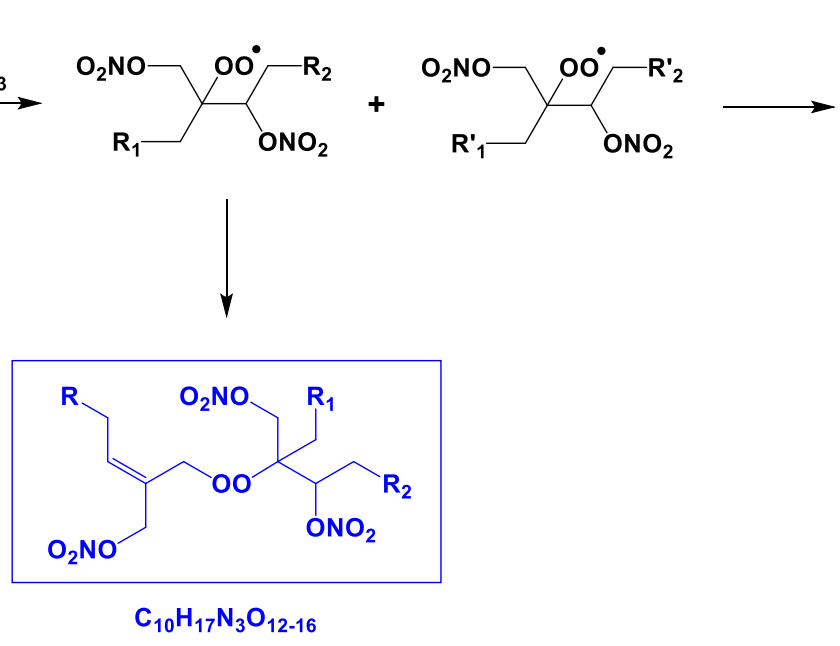

$(\mathrm{m} / \mathrm{z} 450,387,466,482,498$, or 514$)$

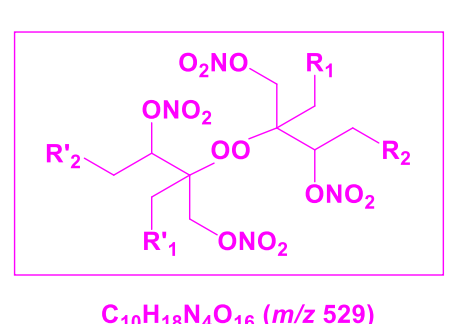

$\mathrm{C}_{10} \mathrm{H}_{18} \mathrm{~N}_{4} \mathrm{O}_{16}(\mathrm{~m} / \mathbf{z} 529)$
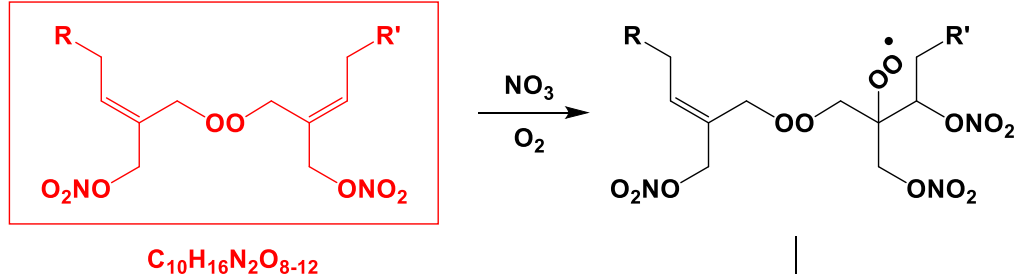

$(m / z 371,387,403,419$, or 435$)$

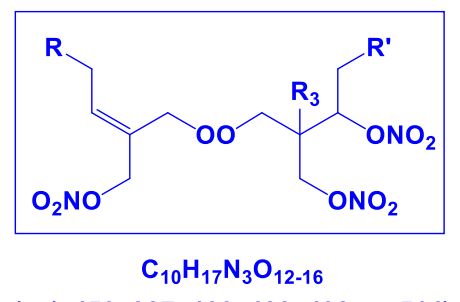

( $m / z 450,387,466,482,498$, or 514$)$

Scheme S13: Proposed formation schematic of different types of dimers (colored by type) through $\mathrm{RO}_{2}+\mathrm{R}^{\prime} \mathrm{O}_{2}$ reaction or further oxidation. Other isomers are possible. Compounds with the given molecular formula in boxes are closed-shell products detected by CIMS at the indicated $\mathbf{m} / \mathbf{z}$ values. 


\section{References}

Aiken, A. C., Decarlo, P. F., Kroll, J. H., Worsnop, D. R., Huffman, J. A., Docherty, K. S., Ulbrich, I. M., Mohr, C., Kimmel, J. R., and Sueper, D.: O/C and OM/OC ratios of primary, secondary, and ambient organic aerosols with high-resolution timeof-flight aerosol mass spectrometry, Environ. Sci. Technol., 42, 4478-4485, 2008.

Al-Naiema, I. M., Hettiyadura, A. P., Wallace, H. W., Sanchez, N. P., Madler, C. J., Cevik, B. K., Bui, A. A., Kettler, J., Griffin, R. J., and Stone, E. A.: Source apportionment of fine particulate matter in Houston, Texas: insights to secondary organic aerosols, Atmos. Chem. Phys., 18, 15601-15622, 2018.

Chen, Q., Farmer, D., Schneider, J., Zorn, S., Heald, C., Karl, T., Guenther, A., Allan, J., Robinson, N., and Coe, H.: Mass spectral characterization of submicron biogenic organic particles in the Amazon Basin, Geophys. Res. Lett., 36, 2009.

Chen, Y., Takeuchi, M., Nah, T., Xu, L., Canagaratna, M. R., Stark, H., Baumann, K., Canonaco, F., Prévôt, A. S., and Huey, L. G.: Chemical characterization of secondary organic aerosol at a rural site in the southeastern US: insights from simultaneous high-resolution time-of-flight aerosol mass spectrometer (HR-ToF-AMS) and FIGAERO chemical ionization mass spectrometer (CIMS) measurements, Atmos. Chem. Phys., 20, 8421-8440, 2020.

Chhabra, P., Flagan, R., and Seinfeld, J.: Elemental analysis of chamber organic aerosol using an aerodyne high-resolution aerosol mass spectrometer, Atmos. Chem. Phys., 10, 4111-4131, 2010.

Daellenbach, K. R., Kourtchev, I., Vogel, A. L., Bruns, E. A., Jiang, J., Petäjä, T., Jaffrezo, J.-L., Aksoyoglu, S., Kalberer, M., and Baltensperger, U.: Impact of anthropogenic and biogenic sources on the seasonal variation in the molecular composition of urban organic aerosols: a field and laboratory study using ultra-high-resolution mass spectrometry, Atmos. Chem. Phys., 19, 5973-5991, 2019.

Hu, W., Hu, M., Hu, W.-W., Zheng, J., Chen, C., Wu, Y., and Guo, S.: Seasonal variations in high time-resolved chemical compositions, sources, and evolution of atmospheric submicron aerosols in the megacity Beijing, Atmos. Chem. Phys., 17, 9979-10000, 2017.

Huang, X.-F., He, L.-Y., Hu, M., Canagaratna, M., Kroll, J., Ng, N., Zhang, Y.-H., Lin, Y., Xue, L., and Sun, T.-L.: Characterization of submicron aerosols at a rural site in Pearl River Delta of China using an Aerodyne High-Resolution Aerosol Mass Spectrometer, Atmos. Chem. Phys., 11, 1865-1877, 2011.

Kim, H., Zhang, Q., and Heo, J.: Influence of intense secondary aerosol formation and long-range transport on aerosol chemistry and properties in the Seoul Metropolitan Area during spring time: results from KORUS-AQ, Atmos. Chem. Phys., 18, 7149$7168,2018$.

Krechmer, J. E., Coggon, M. M., Massoli, P., Nguyen, T. B., Crounse, J. D., Hu, W., Day, D. A., Tyndall, G. S., Henze, D. K., and Rivera-Rios, J. C.: Formation of low volatility organic compounds and secondary organic aerosol from isoprene hydroxyhydroperoxide low-NO oxidation, Environ. Sci. Technol., 49, 10330-10339, 2015.

Krechmer, J. E., Pagonis, D., Ziemann, P. J., and Jimenez, J. L.: Quantification of gas-wall partitioning in Teflon environmental chambers using rapid bursts of low-volatility oxidized species generated in situ, Environmental science \& technology, 50, 5757-5765, 2016.

Lambe, A., Chhabra, P., Onasch, T., Brune, W., Hunter, J., Kroll, J., Cummings, M., Brogan, J., Parmar, Y., and Worsnop, D.: Effect of oxidant concentration, exposure time, and seed particles on secondary organic aerosol chemical composition and yield, Atmos. Chem. Phys., 15, 3063-3075, 2015.

Li, J., Cao, L., Gao, W., He, L., Yan, Y., He, Y., Pan, Y., Ji, D., Liu, Z., and Wang, Y.: Seasonal variations in the highly timeresolved aerosol composition, sources and chemical processes of background submicron particles in the North China Plain, Atmos. Chem. Phys., 21, 4521-4539, 2021. 
Li, Y., Lee, B. P., Su, L., Fung, J. C. H., and Chan, C. K.: Seasonal characteristics of fine particulate matter (PM) based on highresolution time-of-flight aerosol mass spectrometric (HR-ToF-AMS) measurements at the HKUST Supersite in Hong Kong, Atmos. Chem. Phys., 15, 37-53, 2015.

Liu, J., Alexander, L., Fast, J. D., Lindenmaier, R., and Shilling, J. E.: Aerosol characteristics at the Southern Great Plains site during the HI-SCALE campaign, Atmos. Chem. Phys., 21, 5101-5116, 2021.

Massoli, P., Stark, H., Canagaratna, M. R., Krechmer, J. E., Xu, L., Ng, N. L., Mauldin, R. L., Yan, C., Kimmel, J., Misztal, P. K., Jimenez, J. L., Jayne, J. T., and Worsnop, D. R.: Ambient Measurements of Highly Oxidized Gas-Phase Molecules during the Southern Oxidant and Aerosol Study (SOAS) 2013, ACS Earth Space Chem., 2, 653-672, 10.1021/acsearthspacechem.8b00028, 2018.

Nguyen, T. B., Bateman, A. P., Bones, D. L., Nizkorodov, S. A., Laskin, J., and Laskin, A.: High-resolution mass spectrometry analysis of secondary organic aerosol generated by ozonolysis of isoprene, Atmos. Environ., 44, 1032-1042, 2010.

Poulain, L., Spindler, G., Birmili, W., Plass-Dülmer, C., Wiedensohler, A., and Herrmann, H.: Seasonal and diurnal variations of particulate nitrate and organic matter at the IfT research station Melpitz, Atmos. Chem. Phys., 11, 12579-12599, 2011.

Sun, Y., Zhang, Q., Macdonald, A., Hayden, K., Li, S., Liggio, J., Liu, P., Anlauf, K., Leaitch, W., and Steffen, A.: Size-resolved aerosol chemistry on Whistler Mountain, Canada with a high-resolution aerosol mass spectrometer during INTEX-B, Atmos. Chem. Phys., 9, 3095-3111, 2009.

Vereecken, L., Carlsson, P., Novelli, A., Bernard, F., Brown, S., Cho, C., Crowley, J., Fuchs, H., Mellouki, W., and Reimer, D.: Theoretical and experimental study of peroxy and alkoxy radicals in the NO3-initiated oxidation of isoprene, Phys. Chem. Chem. Phys., 23, 5496-5515, 2021.

Wang, D. S., and Ruiz, L. H.: Secondary organic aerosol from chlorine-initiated oxidation of isoprene, Atmos. Chem. Phys., 17, 13491-13508, 2017.

Zhang, X., Cappa, C. D., Jathar, S. H., McVay, R. C., Ensberg, J. J., Kleeman, M. J., and Seinfeld, J. H.: Influence of vapor wall loss in laboratory chambers on yields of secondary organic aerosol, Proceedings of the National Academy of Sciences, 111, 5802-5807, 2014.

Zhang, X., Schwantes, R., McVay, R., Lignell, H., Coggon, M., Flagan, R., and Seinfeld, J.: Vapor wall deposition in Teflon chambers, Atmospheric Chemistry and Physics, 15, 4197-4214, 2015.

Zhang, X., Xu, J., Kang, S., Zhang, Q., and Sun, J.: Chemical characterization and sources of submicron aerosols in the northeastern Qinghai-Tibet Plateau: insights from high-resolution mass spectrometry, Atmos. Chem. Phys., 19, 7897-7911, 2019.

Zhu, Q., He, L.-Y., Huang, X.-F., Cao, L.-M., Gong, Z.-H., Wang, C., Zhuang, X., and Hu, M.: Atmospheric aerosol compositions and sources at two national background sites in northern and southern China, Atmos. Chem. Phys., 16, 10283$10297,2016$. 